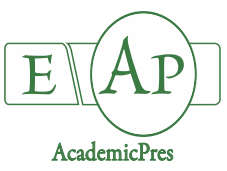

Sun W et al. (2021)

Notulae Botanicae Horti Agrobotanici Cluj-Napoca

Volume 49, Issue 2, Article number 12172

DOI: $10.15835 / \mathrm{nbha} 49212172$

Review Article

\title{
Archaea, bacteria and termite, nitrogen fixation and sustainable plants production
}

\section{Wenli SUN ${ }^{1 a}$, Mohamad H. SHAHRAJABIAN ${ }^{1 a}$, Qi CHENG ${ }^{1,2 *}$}

\author{
${ }^{1}$ Chinese Academy of Agricultural Sciences, Biotechnology Research Institute, Beijing 100081, \\ China;Sunwenli@caas.cn; hesamshahrajabian@gmail.com \\ ${ }^{2}$ Hebei Agricultural University, College of Life Sciences, Baoding, Hebei, 071000, China; Global Alliance of HeBAU-CLS\&HeQiS \\ for BioAl-Manufacturing, Baoding, Hebei 071000,China; chengqi@caas.cn ("corresponding author) \\ ${ }^{a, b}$ These authors contributed equally to the work
}

\begin{abstract}
Certain bacteria and archaea are responsible for biological nitrogen fixation. Metabolic pathways usually are common between archaea and bacteria. Diazotrophs are categorized into two main groups namely: rootnodule bacteria and plant growth-promoting rhizobacteria. Diazotrophs include free living bacteria, such as Azospirillum, Cupriavidus, and some sulfate reducing bacteria, and symbiotic diazotrophs such Rhizobium and Frankia. Three types of nitrogenase are iron and molybdenum (Fe/Mo), iron and vanadium $(\mathrm{Fe} / \mathrm{V})$ or iron only $(\mathrm{Fe})$. The Mo-nitrogenase have a higher specific activity which is expressed better when Molybdenum is available. The best hosts for Rhizobium legumiosarum are Pisum, Vicia, Lathyrus and Lens; Trifolium for Rhizobium trifolii; Phaseolus vulgaris, Prunus angustifolia for Rhizobium phaseoli; Medicago, Melilotus and Trigonella for Rhizobium meliloti; Lupinus and Ornithopus for Lupini, and Glycine max for Rhizobium japonicum. Termites have significant key role in soil ecology, transporting and mixing soil. Termite gut microbes supply the enzymes required to degrade plant polymers, synthesize amino acids, recycle nitrogenous waste and fix atmospheric nitrogen. The positive effects of Arbuscular mycorrhizal (AM) fungi such as growth promotion, increased root length, leaf area, stem diameter, transplant performance and tolerance to stresses have been reported previously.
\end{abstract}

Keywords: Archaea; Azotobacter; bacteria; nitrogenase; nitrogen fixation; termite

\section{Introduction}

Nitrogen is a key factor in protein and nucleic acids and all organisms need nitrogen (Benavides et al., 2013). Moreover, nitrogen is the major limiting nutrient for plant biomass production in environment (Nardi et al., 2002). It is the most important parameters for the synthesis of amino acids, DNA, RNA and proteins (Fowler et al., 2013; Rago et al., 2019). Several processes such as nitrogen fixation, dissimilatory nitrate reduction to ammonia, nitrification, anammox, and denitrification carried out by microbes. Biological nitrogen fixation is called the most critical biological process in the world (Kizilkaya, 2009). Bacteria and archaea inhabit the most inhospitable environments and have unique roles in metabolic pathways and genes to cope with different environmental conditions (Smith-Moore and Grunden, 2018). They are fund inhabiting the 
rhizosphere with numerous interactions with the plant host (Odelade and Babalola, 2019). So, this review explores various unique beneficial microbes, especially archaea, bacteria, and their especial roles in the environment according to acquisition of nutrients for plant growth and improve productivity.

\section{Nitrogen}

Nitrogen $(\mathrm{N})$ is a vital parameter for crop productivity (Egamberdieva and Kucharova, 2008; Broumadet al., 2010; Soleymani et al., 2011 a,b). Nitrogen is most important limiting nutrient for crop production and plant productivity in many parts of the world (Mitchell et al., 2018; Sun et al., 2019). It is also a manin part in chlorophyll as well as key parameter in amino acids and proteicn (Olson and Kurtz, 1982; Hammad and Ali, 2014; Kumar et al., 2017; Mahato and Kafle, 2018). One of the most important nutrient cycles in ecosystem is biological nitrogen cycle which includes four main processes, namely, nitrogen fixation, mineralization (decay), nitrification and denitrification (Mao et al., 2011; Xiao et al., 2019). The most important functional genes are nifH, amo $A$, and nosZ genes which are participate in encoding key enzymes in nitrogen fixation, ammonia oxidation and complete denitrification, respectively (Ruiz-Rueda et al., 2009; Bru et al., 2011; Orr et al., 2011). Mao et al. (2011) indicated that utilization of nitrogen fertilizer many have both short-term environmental problems, and long-term impact on the global biogeochemical cycles via altering the soil microbial community structure and abundance. The global nitrogen cycle represents the transformation of nitrogen gases and nitrogen-containing compound which consists of microbial-driven processes, such as assimilation, ammonification, nitrification, denitrification, nitrogen fixation and anaerobic oxidation (You et al., 2009).

\section{Nitrogen fixation}

Nitrogen fixation has also significant role in biochemical pathways which play an important role in controlling oceanic nitrogen inventory (Ohkuma et al., 1996; LaRoche and Breitbarth, 2005; Sylvia et al., 2005; Cotta et al., 2014). Without any doubt, nitrogen fixation is an ancient way which is essential for surviving life, and play a key role during the beginning of microbial life when abiotic nitrogen sources become scarce (Raymond et al., 2004; Gaby and Buckley, 2014). Nitrogenase plays an important part in global nitrogen cycle (Soleymani et al., 2012; Shahrajabian and Soleymani, 2017), and understanding of nitrogenase expression and regulation is important to utilize potential diazotrophs under various ecological niches to gain agricultural and environmental sustainability at the same time (Kargi and Ozmihci, 2002; Suyalet al., 2018). Nitrogen fixation is divided into two parts abiotic methods (lightning), and biotic (nitrogen fixers) to fix nitrogen to the ground. In the abiotic fixation, $\mathrm{N}_{2}$ would have been oxidized with $\mathrm{CO}_{2}$ by lightning, and then $\mathrm{NO}$ gets converted to soluble nitrosyl hydride (HNO) (Navarro-Gonzalez et al., 2011). In the Ocean, dissolved N2 would have been converted into $\mathrm{NO}_{3}{ }_{3}$ and $\mathrm{NO}_{2}{ }^{-}$(Mancinelli and Mckay, 1998). Certain bacteria and archaea are responsible for biological nitrogen fixation. Although, there is large atmospheric reservoir, bioavailability of nitrogen mostly relies on biological nitrogen fixation (BNF) (Prayitno and Rolfe, 2010). Two main drivers of universal nitrogen cycling are ammonia-oxidizing bacteria (AOB), and archaea (AOA) (Long et al., 2012). Metabolic pathways usually are common between archaea and bacteria (Smith-Moore and Grunden, 2018; Odelade et al., 2019), and almost all genes involved in this process are founder under these domains (Tatusov et al., 2003). It has been found that a lone bilayer lipid which makes the cell structural formation of archaea is very close to the bacterial cell which is gram-positive within prokaryota (Makarova et al., 2001). One of the most important proteins which are common to both archaea and gram-positive bacteria are glutamine synthetase I and Hsp70 (Makarova et al., 2001; Hugenholtz, 2002; Koch, 2003). Nitrogen fixation is energetically expensive because it consumes 16 moles of ATP per mole of N fixed (Aisalbie and Deslippe, 2013). Nitrogen fixation also has been considered as the limiting factor for both crop and natural ecosystem productivity which has shown scholars the importance of this process in agricultural system (Dixon and Kahn, 2004). Relying on chemical fertilizer, 
especially nitrogen may lead to both serious health issues and environmental concern (Shahrajabian et al., 2011; Shahrajabian et al., 2019), and it is the barrier for the goal of having sustainable agriculture and organic life (Soleymani and Shahrajabian, 2012). Nitrogenase is an ATP-hydrolyzing, redox-active complex of two component proteins, the dinitrogenase reductase $\gamma_{2}$ homodimer (NifH protein), and the dinitroenase $\alpha_{2} \beta_{2}$ heterotetramer, where $\alpha$ is NifD, and $\beta$ is NifK proteins (Raymond et al., 2004). The molybdenum nitrogenase is an oxygen sensitive complex dinitrogenase (NifDKheterotetramer), and dinitrogenase reductase (NifH homodimer) (Ortiz-Marquez et al., 2014). $\mathrm{MoFe}_{7} \mathrm{~S}_{9}$ metal cluster is the active site for dinitrogen reduction for $\alpha$, however, is some organisms Mo is replaced by either Fe or V, which is called Anf and Vnf, respectively instead of Nif (Raymond et al., 2004). It has been reported that FeMo nitrogenase has been recognized to be more efficient in binding dinitrogen and reducing it to ammonia compare with alternative nitrogenase (Nif $>$ Vnf $>$ Anf) (Joerger and Bishop, 1988; Miller and Eady, 1988). Via the enzyme nitrogenase, microorganisms catalyze nitrogen fixation, which has been highly conserved throughout evolution (Hrynkiewicz et al., 2019). All $\mathrm{N}_{2}$ fixers carry the nif(nitrogen fixation) genes, which encoded the nitrogenase complex (Argandona et al., 2005). Nitrogenase is definitely sensitive to oxygen, which is why a specific oxygen barrier is formed around the infected cells by a cell layer which may reduce oxygen level in nodule cortex (Ribeiro et al., 2015). Keshri et al. (2013) also reported that the key functional genes namely cbbL, nifH, amoA, and apsAinvolced in various nutrient cycling. The genes which encoding of enzymes in nitrification process are ammonium monooxygenase (amo), hydroxylamine oxidoreductase (hao), and nitrite oxidoreducatse ( $n x r)$, whereas those that conduct denitrification consist of nitrite reductases (nir $\mathrm{K}, n i r S$ ), nitric oxide reductase (nor $\mathrm{B}$ ), and nitrous oxide reductase (nosZ) (Brauman et al., 2015). The genes which are most commonly used as functional markers to assess both the nitrification and denitrification processes are amo, nir K, nirS and nosZ (Levy-Booth et al., 2014). The nif operon includes the nitrogenase structural gene niff, which has been sequenced to provide a large database from different environments (Zehr et al., 2003; Argandona et al., 2005). The additional of external organic matter provides a good source of energy and nutrients to support growth, because many of the microorganisms participating in N2 fixation are heterotrophic or mixotrophic (Rahav et al., 2016; Tang et al., 2017). Also, niff has been used as a molecular marker to determine diazotroph indices, which encodes a nitrogenase iron protein (Che et al., 2018; Chen et al., 2019). The characterization of diazotroph communities by nifH genes could be a potential indirect approach to the assessment of levels of biological N fixation in soils (Reardon et al., 2014). Tsoy et al. (2016) stated that in most nitrogen-fixing bacteria NifA is the master regulator of nitrogen fixation as it works in relationship with the RNA-plymerase sigma factor RpoN (Sullivan et al., 2002; Sciotti et al., 2003). Both phosphorus (P) deficiency and potassium $(\mathrm{K})$ deficiency resulted in significant decreases in niff gene expression and $\mathrm{N}_{2}$-fixation activity, and $\mathrm{P}$ deficiency exhibited more restricted impacts (Tang et al., 2017). Dinitrogenase reductase (azoferredoxin), and dinitrogenase (molybdoferredoxin) are two principal subunits of the nitrogenase complex (Hageman and Burris, 1978), and Nif (nitrogen fixing) proteins NifH ( $\gamma_{2}$ homodimericazoerredoxin), and NifD/K $\left(\alpha_{2} \beta_{2}\right.$ heterotetramericmolybdoferredoxin) are the structural components of these subunits (Kneip et al., 2007). Three types of nitrogenase are iron and molybdenum $(\mathrm{Fe} / \mathrm{Mo})$, iron and vanadium $(\mathrm{Fe} / \mathrm{V})$ or iron only $(\mathrm{Fe})$ (Bishop et al., 1986; Chisnell et al., 1988; Bishop and Premakumar, 1992). The Mo-nitrogenase has a higher specific activity which is expreseed better when Mo is available (Eady, 2003; Betancourt et al., 2008). Although, all bacteria which have role in nitrogen fixation possess the Mo-nitrogenase, but just some of them have the genes for the V-and Fe-nitrogenase or both (Bellenger et al., 2014). Tsoy et al. (2016) noted that all known nitrogenases need a FeS-cluster and some other metal-dependent cofactors for transduction. The most common metal-dependent cofactor is the molybdenum-dependent nitrogenase which is encoded by the nifHDK genes (Barns et al., 1996; Sabra et al., 2000; Kneip et al., 2007; Boyd and Peters, 2013; Offre et al., 2013; Ulyshen, 2015). Other notable nitrogenases are vanadium- and iron-dependent nitrogenases encoded by the vnfHDGK and anfHDGK genes, respectively (Rehder, 2000; Herridge et al., 2008; Seefeldt et al., 2009; Hartmann and Barnum, 2010). There are different ways of nitrogen fixing from unavailable gaseous forms in the atmosphere to usable forms for plants and other organisms. 
Diazotrophs are categorized into two main groups namely: root-nodule bacteria and plant growthpromoting rhizobacteria (PGPR). Root-noduce bacteria cosnsit of rhizobia and Frankia. Rhizobia which include alpha-and betaproteobacteria enter into a symbiotic association with legumes and Frankia with actinorhizal plants. Some other palnts develop endosymbiotic interactions with nitrogen-fixing cyanobacteria (Nostoc). PGPRs consist of proteobacteria (alpha-, beta-, and gammaproteobacteria), actnobacteria, bacilli, and cyanobacteria (Chain et al., 2003; Papineau et al., 2005; Kneip et al., 2007; Philippotet al., 2007; Shridhar, 2012; Mus et al., 2016). The oxidation of ammonia is done by ammonia oxidizers (both archaea and bacteria), and the nitrite produced is finally oxidized by nitrite-oxidizing bacteria. In bacteria, ammonia is oxidized to nitrite via the intermediate hydroxylamine and the enzyme hydroxylamine oxidoreductase (HAO). Functional characterization of upregulated and downregulated selected proteins during low temperature $\mathrm{N}$ depletion is shown in Table 1. Homologs of the nifH is indicted in Table 2.

Table 1. Functional characterization of upregulated and downregulated selected proteins during low temperature $\mathrm{N}$ depletion condition by Pseudomonas palleroniana N26 as revealed by LC-MS/MS analysis (Suyal et al., 2018)

\begin{tabular}{|c|c|c|}
\hline Genes & Proteins & Biological functions \\
\hline \multicolumn{3}{|c|}{ Upregulated proteins (BM) } \\
\hline nifH & Nitrogenase iron protein & Nitrogen fixation \\
\hline nifA & nif-specific regulatory protein & Activation of most nif operons \\
\hline nifL & Nitrogen fixation regulatory protein & Regulation of nitrogen fixation \\
\hline nißB & FeMo cofactor biosynthesis protein & $\begin{array}{l}\text { Biosynthesis of the iron- } \\
\text { molybdenum cofactor }\end{array}$ \\
\hline nifD & $\begin{array}{c}\text { Nitrogenase molybdenum-iron } \\
\text { protein }\end{array}$ & Nitrogen fixation \\
\hline nifK & $\begin{array}{c}\text { Nitrogenase molybdenum-iron } \\
\text { protein }\end{array}$ & Nitrogen fixation \\
\hline nirs & Nitrite reductase & Nitrite reduction \\
\hline hemE & Uroporphyrinogen decarboxylase & Porphyrin biosynthesis \\
\hline guaA & GMP synthase & Purine biosynthesis \\
\hline$p y_{I} \mathrm{G}$ & CTP synthase & Glutamine metabolic process \\
\hline polA & DNA polymerase I & DNA replication \\
\hline pheT & $\begin{array}{c}\text { Phenylalanine-tRNA ligase beta } \\
\text { subunit }\end{array}$ & Phenylalanyl-tRNA aminoacylation \\
\hline groEL & 60 kDachperonin & Protein refolding \\
\hline$g y r \mathrm{~B}$ & DNA gyrase subunit B & DNA topological change \\
\hline$r p / E$ & $50 S$ ribosomal protein $\mathrm{L} 1$ & Ribosomal large subunit assembly \\
\hline rp/A & $50 \mathrm{~S}$ ribosomal protein $\mathrm{L} 1$ & Translation regulation \\
\hline mur $\mathrm{D}$ & $\begin{array}{l}\text { UDP- } N \text {-acetylmuramoylalanine-D- } \\
\text { glutamate ligase }\end{array}$ & Cell division \\
\hline uvr $\mathrm{B}$ & UvrABC system protein B & DNA damage \\
\hline$g / m S$ & $\begin{array}{c}\text { Glutamine-fructose-6-phosphate } \\
\text { aminotransderase }\end{array}$ & Glutamine metabolic process \\
\hline alas & Alanine-tRNA ligase & Alanyl-tRNA aminoacylation \\
\hline$r p s \mathrm{~F}$ & $30 \mathrm{~S}$ ribosomal protein $\mathrm{S} 6$ & Translation \\
\hline tig & Trigger factor & Cell division \\
\hline$t r u \mathrm{~B}$ & tRNA pseudouridine synthase B & tRNA processing \\
\hline truA & tRNA pseudouridine synthase A & tRNA processing \\
\hline pros & Proline-tRNA ligase & Prolul-tRNA aminoacylation \\
\hline$g \ln S$ & Glutamine-tRNA ligase & Glutamyl-tRNA aminoacylation \\
\hline hisS & Histidine-tRNA ligase & Protein biosynthesis \\
\hline $\sec \mathrm{A}$ & Protein translocase subunit SecA & Protein transport \\
\hline
\end{tabular}


Sun W et al. (2021). Not Bot Horti Agrobo 49(2):12172

\begin{tabular}{|c|c|c|}
\hline glyA & Serine hydroxymethyltransderase & Amino-acid biosynthesis \\
\hline $\operatorname{atp} \mathrm{G}$ & ATP synthase gamma chain & ATP synthesis \\
\hline $\operatorname{trmD}$ & $\begin{array}{l}\text { tRNA (guanine-N91)-)- } \\
\text { methyltransderase }\end{array}$ & $\mathrm{tRNA}$ processin \\
\hline$m f d$ & Transcription-repair-coupling factor & DNA repair \\
\hline leu $\mathrm{C}_{2}$ & $\begin{array}{c}\text { 3-isopropylmalate dehydratase large } \\
\text { subunit } 2\end{array}$ & Amino-acid biosynthesis \\
\hline$s d h \mathrm{~A}$ & $\begin{array}{c}\text { Succinate dehydrogenase flavoprotein } \\
\text { subunit }\end{array}$ & Electron transport \\
\hline yacG & DNA gyrase inhibitor & Stress control \\
\hline $\operatorname{cow} \mathrm{N}$ & $\begin{array}{c}\mathrm{N}(2) \text {-fixation sustaining protein } \\
\text { CowN }\end{array}$ & Protecting nitrogenase from $\mathrm{CO}$ \\
\hline $\operatorname{cooA}$ & $\begin{array}{l}\text { Carbon monoxide oxidation } \\
\text { transcription regulator }\end{array}$ & $\mathrm{CO}$ regulator \\
\hline
\end{tabular}

Table 2. Homologs of the nifH gene can be divided into five main phylogenetic clusters

Cluster I contains a diverse group of nif $\mathrm{H}$ genes primarily from aerobic and facultatively anaerobic organisms which belong to phyla including Proeobacteria, Cyanobacteria, Firmicutes and Actinobacteria (Chien and Zinder, 1994)

Cluster II contains anf $H$, alternative nitrogenase which are paralogs of nif $H$ and use an Fe-Fe cofactor in place of the Fe-Mo cofactor used by nifH. There also exist V-Fe alternative nitrogenases encoded by $v n f H$, and the alternative nitrogenases appear to be found only in the genomes of organisms which also contain nif genes.

Cluster III contains nifH genes that are almost exclusively found in obligate anaerobes including methanogenic Archaea, Treponema, Clostridium and sulfate-reducing and sulfur-reducing species of Deltaproteobacteria (Chien and Zinder, 1994)

Cluster IV and V contain paralogous genes which do not participate in nitrogen fixation (Souillard et al., 1988; Fujia et al., 1992; Raymond et al., 2004; Nomata et al., 2006; Staples et al., 2007).

\section{Diazotrophs}

Diazotrophs have a vital role in fixing atmospheric nitrogen $(\mathrm{N})$ in terrestrial ecosystems (Koskeyet al., 2017; Wang et al., 2017; Xiao et al., 2020). The estimate areas of biological nitrogen fixation and related factors controlling BNF is done by diazotroph distribution (Ratten et al., 2015; Lin et al., 2018; Yang et al., 2019), which contributes to the sustainability of agricultural ecosystems (Reed et al., 2011). Diazotrophic community structure and diversity also mostly correlated with soil pH (Feng et al., 2018). Mosiander et al. (2012) showed that the free-living diazotrophs contributing to nitrogen fixation changes considerably and is mostly dependent on the soil nitrogen content. Diazotrophs are highly diverse an include members of $\alpha$-, $\beta$-, and $\delta$-Proteobacteria, Firmicutes, Cyanobacteria, and Archaea (Rosch et al., 2002; Reardon et al., 2014). Diazotrophs include free living bacteria, such as Azospirillum, Cupriavidus, and some sulfate reducing bacteria, and symbiotic diazotrophs such Rhizobium and Frankia (Knothet al., 2013; Sellstedt and Richau, 2013; Yin et al., 2018).Dixon and Kahn (2004) found that diazotrophs are found in a broad diversity of habitats: free-living in water and soil, symbiotic association in termite guts, associative symbioses with grasses, cyanobacterial symbioses with different plants, actinorhizal relationship with woody plants, and root-nodule symbioses with legumes. Biological nitrogen fixation by diaotophic bacteria in seagrass rhisozphere and leaf epiphytic community is also another considerable source of this process (Hemmina and Duarte, 2000; Welsh, 2000; Lee et al., 2007; Garcias-Bonet et al., 2016). Nitrogen fixing plants can provide diverse impacts on diazotrophs under both nitrogen limitation or saturation (Biswas and Gresshoff, 2014; Xiao et al., 2020). A range of diazotrophic plant growth-promoting rhizobacteria which meaningfully boost the vegetative growth and final grain yield, participate in interactions with $\mathrm{C}_{3}$ and $\mathrm{C}_{4}$ crop plants such as rice, wheat, maize, sugarcane and cotton (Kennedy et al., 2004). The combination of intracellular symbiotic nitrogen fixation, may lead to increase rates of photosynthesis and presence of supplementary plant growh factors in cereals and other non- 
legumes (Evans, 1983; Gillis et al., 1989; Fuentes-Ramirez et al., 1993; Sevilla et al., 2001; Momose et al., 2013; Dent and Cocking, 2017). Xiao et al. (2020) concluded that diazotroph abundance may respond to differences in the density with leguminous plants. Ke et al. (2019) revealed that soil compartment and different inoculation treatments were the main factors affecting the distribution of the diazotrophic community. Pereira et al. (2013) noted that two important parameters which may affect diazotroph communities are temperature and soil moisture in different seasons. Che et al. (2018) also noted that among all environmental factors, the soil moisture, organic carbon, available phosphorus, and inorganic nitrogen contents could be the main drivers of diazotroph distribution. Agronomic practices may also have impact on soil diazotrophs, such as application of nitrogen fertilizer which may reduce the diversity of diazotrophs (Tan et al., 2003). It has been reported that nitrogen supply is closely connected to soil diazotrophs, which shows the nitrogen supply capacity of soil (Dixon and Kahn, 2004; Reed et al., 2011). Chen et al. (2014) showed that the unicellular diazotrophs are important $\mathrm{N}_{2}$ fixers and contributed significantly to $\mathrm{N}_{2}$ fixation in the tropical marginal seas. Chen et al. (2019) also confirmed that diazotrophic activity of heterotrophic Proteobacteria should be considered as an important part of nitrogen cycle in oceanic systems. Trichodesmium spp. and diatom-symbiotic Calothrix rhizosoleniae and Richeliaintracellularis are important marine diazotrophs (Capone et al., 1997; Gomez et al., 2005), and it is believed that most of the biological nitrogen fixation in the ocean is performed by them (Foster et al., 2007; Shiozaki et al., 2014). The best hosts for Rhizobium legumiosarum are pisum, vicia, lathyrus and lens; Trifolium for $R$. trifolii; Phaseolous vulgaris, P. angustifolia for $R$. phaseoli; Medicago, Melilotus and Trigonella for $R$. meliloti; Lupinus and Ornithopus for Lupini, and Glycine max for $R$. japonicum. LaRoche and Breitbarth (2005) found that Trichosemium is one of the superior marine diazotrophs. Microbial domains comparisons are indicated in Table 3.

Table 3. Microbial domains comparisons (Wang et al., 2007)

\begin{tabular}{|c|c|c|c|}
\hline Property & Bacteria & Archaea & Fungi \\
\hline Cell membrane & $\begin{array}{l}\text { Made up of peptidoglycan and } \\
\text { lipids are linked via ester molecule }\end{array}$ & $\begin{array}{l}\text { Made up of pseudo- } \\
\text { peptidoglycan and lipids are } \\
\text { linked via ether molecule }\end{array}$ & $\begin{array}{c}\text { Made up of different } \\
\text { structures and lipids are } \\
\text { linked via ester molecule }\end{array}$ \\
\hline $\begin{array}{l}\text { Gene structure } \\
\text { and } \\
\text { configuration }\end{array}$ & $\begin{array}{c}\text { Chromosomes are circular, } \\
\text { translation and transcription are } \\
\text { unique }\end{array}$ & $\begin{array}{l}\text { Chromosomes are circular, } \\
\text { translation and transcription } \\
\text { are similar to eukaryotes } \\
\text { (fungi) }\end{array}$ & $\begin{array}{l}\text { Chromosomes are multiple } \\
\text { and linear, translation and } \\
\text { transcription are similar to } \\
\text { archaea }\end{array}$ \\
\hline $\begin{array}{l}\text { Structure of } \\
\text { internal cell }\end{array}$ & $\begin{array}{l}\text { The nucleus or organelles has no } \\
\text { membrane bound }\end{array}$ & $\begin{array}{l}\text { The nucleus or organelles } \\
\text { has no membrane bound }\end{array}$ & $\begin{array}{c}\text { There is membrane bound } \\
\text { nucleus and organelles }\end{array}$ \\
\hline $\begin{array}{l}\text { Metabolic } \\
\text { reaction }\end{array}$ & $\begin{array}{l}\text { There are several, including } \\
\text { aerobic and anaerobic respiration, } \\
\text { photosynthetic, autotrophic } \\
\text { reactions and fermentation }\end{array}$ & $\begin{array}{c}\text { There are several with } \\
\text { methanogenic reaction } \\
\text { specifically unique to this } \\
\text { domain }\end{array}$ & $\begin{array}{l}\text { Cellular respiration, } \\
\text { fermentation and } \\
\text { photosynthetic reaction }\end{array}$ \\
\hline Reproduction & $\begin{array}{l}\text { Reproduction is asexual and } \\
\text { transfer of genes is horizontal }\end{array}$ & $\begin{array}{c}\text { Reproduction is asexual and } \\
\text { transfer of genes is } \\
\text { horizontal }\end{array}$ & $\begin{array}{c}\text { Reproduction is sexual and } \\
\text { asexual }\end{array}$ \\
\hline
\end{tabular}

Free-living and symbiotic nitrogen fixing bacteria are a) archeae which have two divisions, methanosarcinales, and methanobacteriales, b) bacteria which consists of divisions namely cyanobacteria, actinobacteria, proteobacteria, firmicutes (Clostridia), bacteroidetes/chlorobiales, spirochaetales and chloroflexi (Kneipet al., 2007). Phylogenetic affinities of symbiotic and non-symbiotic nitrogen fixing bacteria. Azotobacter species (Azotobacter vinelandii and A. chroococcum) are free-living, aerobic heterotrophic diazotrophs that rely on an adequate supply of reduced C compounds like sugars for energy (Kenndey et al., 2004). Azospirillum species aerobic heterotrophs that fix $\mathrm{N}_{2}$ under microaerobic conditions (Roper and Ladha,1995), which grow widely in the rhizosphere of gramineous plants (Kennedy and Tchan, 1992). Acetobacter (Gluconacetobacter) diazotrophicus is an acid-tolerant endophyte which grows best on sucrose- 
rich medium (James et al., 1994). Azorhizobium caulinodans increased the dry weight and N content of wheat plants in a green house experiment (Matthews et al., 2001). Herbaspirillum is an endophyte which colonises sugarcane, rice, maize, sorghum and other cereals (James et al., 2000). Biology and potential role of some diazotrophs are shown in Table 4.

Table 4. Biology and potential role of some diazotrophs promoting crop production (Kenndey et al., 2004)

\begin{tabular}{|l|c|c|c|c|}
\hline \multicolumn{1}{|c|}{ Diazotrophs } & $\begin{array}{c}\text { Condition for } \\
\text { BNF }\end{array}$ & Habitat & $\begin{array}{c}\text { Energy } \\
\text { source }\end{array}$ & $\begin{array}{c}\text { Mechanism } \\
\text { of effect }\end{array}$ \\
\hline A. chroococcum & Aerobic & Rhizosphere & Organics in soil & BNF \\
\hline Clostridium spp. & Anaerobic & Soil saprophyte & Organics in soil & BNF \\
\hline Azospirillum spp. & Microaerobic & $\begin{array}{c}\text { Rhizosphere, mildly endophytic } \\
\text { in roots, stems and leaves }\end{array}$ & $\begin{array}{c}\text { Organics in soil, root } \\
\text { exudates and plant tissue }\end{array}$ & BNF, PGP \\
\hline H. seropedicae & Microaerobic & Endophytic, rhizosphere & Root exudates & BNF, PGP \\
\hline Azoarcus sp. & Microaerobic & Endophytic & Root exudates & BNF \\
\hline A. vietnamiensis & - & Rhizosphere, endophytic & $\begin{array}{c}\text { Organics in soil and root } \\
\text { exudates }\end{array}$ & BNF, PGP \\
\hline $\begin{array}{l}\text { R. leguminosarum } \\
\text { b. Trifolii }\end{array}$ & - & Endophytic in roots & Root exudates & PGP \\
\hline R. etlibv. phaseoli & - & Endophytic in roots & Root exudates & PGP \\
\hline A. caulinodans & Microaerobic & Endophytic in roots & Root exudates & PGP \\
\hline A. diazotrophicus & Microaerobic & $\begin{array}{c}\text { Endophytic in roots, stems and } \\
\text { leaves }\end{array}$ & $\begin{array}{c}\text { Root exudates and plant } \\
\text { tissue }\end{array}$ & BNF \\
\hline
\end{tabular}

BNF, Biological nitrogen fixation; PGP, plant growth promotion.

Termites

Termites are insects belonging to the order Isoptera (Gomathi et al., 2018). Termites often divided into two broad classes, a) those that nest in and feed on a single source of dead plant material such as felled dead wood for the whole lifespan of the colony, and those that forage outside the nest (Higashi et al., 1992; Tokuda et al., 2012; Sapountzis et al., 2016). Soil-feeding species are able to feed on nitrogenous soil components such as peptides, proteins and amino acid (Kappler and Brune, 2000; Brune, 2001), while wood-feeding termites can thrive on nutrient-poor materials (Tayasu et al., 1994). It has been reported that the soil organic matter in the termitoshpere is significantly more stable and protected from the intense mineralization compared to the control soil (Brauman, 2000). Unlike reported results, Majeed et al. (2012) found that wood-feeding termites were able to take up atomospheric $\mathrm{N}_{2} \mathrm{O}$. Symbiotic nitrogen $\left(\mathrm{N}_{2}\right)$ fixation occurs in a wide variety of trees, and the endosymbionts in legume trees and in the non-legume genus Parasponia (Ulmaceae) are rhizobia (Sprent and Parsons, 2000). Wood-eating termites feed on a diet highly deficient in nitrogen (Frohlich et al., 2007). Curtis and Waller (1998) deduced that termites nitrogenase activity was highest in autumn and spring. Ulyshen (2015) found that by accelerating the release of nutrients immobilized in fungal tissues and promoting $\mathrm{N}_{2}$ fixation by free-living and endosymbiotic prokaryotes, saproxylic insects have potential to influence $\mathrm{N}$ dynamic in forests. Termites have been used as a biological pointer to evaluate both quality and fertility of soil, because of their important role in nitrogen fixation, methanogensis, soil transportation, nutrient circulation and acetogenesis (Dawes, 2010; Brauman et al., 2015; Enagbonma and Babalola, 2019). They have been also known as gold mine of bacterial communities (Benndorf et al., 2018; Devi and Thakur, 2018; Kumar et al., 2018; Enagbonma and Babalola, 2019). $\mathrm{N}_{2}$-fixing activity has been showed in the termite gut, because woodfeeding termites must supplement their food with nitrogen (Breznaket al., 1973; French et al., 1976; Bentley, 1984). It could be accomplished with the aid of nitrogen-fixing bacterial isolates, such as Enterobacter, Desulfovibrio, and Treponema species (Breznak et al., 1973; Kuhnigket al., 1996; Lilburn et al., 2001). 
Table 5. Examples of timber producing nitrogen fixing legume trees (Allen and Allen, 1981)

\begin{tabular}{|l|c|}
\hline \multicolumn{1}{|c|}{ Species } & Some uses \\
\hline Melanoxylon brauna & Construction; tannin \\
\hline Erythrophleum suaveolens & Construction; charcoal \\
\hline Campsiandra laurifolia & Construction; starch (seeds); medicinal \\
\hline \multicolumn{2}{|c|}{ Mimosoideae } \\
\hline Acacia senegal & Tools; charcoal; gum Arabic; fodder \\
\hline Albizia lebbeck & Construction; shade; fodder \\
\hline Anadenanthera colubrine & Construction; gum; hallucinogenic drugs \\
\hline Enterolobium cyclocarpum & Constrion; tannin (pods); soap; drugs \\
\hline \multicolumn{2}{|c|}{ Papilionoideae } \\
\hline Andira inermis & Construction; ornament; shade; drugs \\
\hline Hymenolobium excelsum & Construction \\
\hline Robinia pseudoacacia & Construction; toxins; reclamation \\
\hline Swartzia madagascariensis & Construction; edible fruit \\
\hline Xanthocercis madagascariensis & \multicolumn{2}{c|}{. } \\
\hline
\end{tabular}

Termite gut microbes supply the enzymes required to degrade plant polymers, synthesize amino acids, recycle nitrogenous waste and fix atmospheric nitrogen $\left(\mathrm{N}_{2}\right)$ (Bignell, 2000; Brune and Ohkuma, 2010; Sapountzis et al., 2016). It has been reported that termites depend on a range of microflora in their guts to promote digestion of the plant material (Gomathi et al., 2018). Sprent and Parsons (2000) found that the success depends on both their ability to fix $\mathrm{N}_{2}$ symbiotically, but also on a range of other adaptations as well as flooding and drought tolerance, mycorrhizal formation, cluster root production and herbivore defenses. Fall et al. (2001) showed that termite mound soil has nearly more than two times calcium and phosphorus, and approximately five times carbon and nitrogen, as well as 50 times ammonia and organic matter than other soil experiments. Microctermes, Nasutitermes, and Macrotermes are main termites of forest vegetation (Gomathi et al., 2018). Some examples of timber producing nitrogen fixing legume trees are shown in Table 5. Examples of non-nodulated legumes used for timber are shown in Table 6. $\mathrm{N}_{2}\left(\mathrm{C}_{2} \mathrm{H}_{2}\right)$ fixation in termites is presented in Table 7. $\mathrm{N}_{2}\left(\mathrm{C}_{2} \mathrm{H}_{2}\right)$ fixation in other insects is indicated in Table 8.

Table 6. Examples of non-nodulated legumes used for timber (Sprent and Parsons, 2000)

\begin{tabular}{|l|c|}
\hline \multicolumn{1}{|c|}{ Species } & Some uses \\
\hline Caesalpinioideae & Construction; dyes \\
\hline Caesalpinia echinata & Construction (local); fodder, drugs \\
\hline Gleditsia triacanthos & Carving; fodder; ornamental \\
\hline Parkinsonia aculeata & \\
\hline & \\
\hline Mimosoideae & Construction; jewelry (seeds); drugs \\
\hline Adenanthera pavonina & Construction; food; fodder \\
\hline Parkia biglobosa & Construction; food; drugs \\
\hline Tetrapleura tetraptera & \\
\hline & \\
\hline Papilionoideae & Construction; food; gum \\
\hline Dipteryx odorata & Construction (local); drugs \\
\hline Vataria guianensis & Construction; drugs; tannins \\
\hline Zollernia falcata & \\
\hline
\end{tabular}


Table 7. $\mathrm{N}_{2}\left(\mathrm{C}_{2} \mathrm{H}_{2}\right)$ fixation in termites (Mertins, 1973)

\begin{tabular}{|l|c|c|}
\hline \multicolumn{1}{|c|}{ Termite } & Caste & Diet \\
\hline Coptotermes formosanus & Worker & Wood (colony) \\
\hline Reticulitermes flavipes & Soldier & Wood (colony) \\
\hline & Worker & Wood (colony) \\
\hline Zootermopsis sp. & Soldier & Wood (colony) \\
\hline Cryptotermes brevis & Reproductive nymphs and workers & Moist filter paper (12h) \\
\hline
\end{tabular}

Table 8. $\mathrm{N}_{2}\left(\mathrm{C}_{2} \mathrm{H}_{2}\right)$ fixation in other insects (Mertins, 1973)

\begin{tabular}{|l|c|}
\hline \multicolumn{1}{|c|}{ Insect } & Common name \\
\hline Acyrthosiphon pisum & Pea aphid \\
\hline Attagenus megatoma & Black carpet beetle \\
\hline Blattella germanica & German cockroach \\
\hline Camponotus sp. & Carpenter ant \\
\hline Dermestes maculates & Hide beetle \\
\hline Drosophila melanogaster & Fruit fly \\
\hline Lasioderma serricorne & Cigarette beetle \\
\hline Mezium americanum (adults and larvae) & Spider beetle \\
\hline Musca domestica & House fly \\
\hline Oncopeltus fasciatus & Milkweed bug \\
\hline Periplaneta americana & American cockroach \\
\hline Rhyzopetha dominica & Lesser grain borer \\
\hline Stegobium paniceum & Drugstore beetle \\
\hline Supella supellectilium & Brown-banded cockroach \\
\hline Tenebrio molitor (Larvae) & Yellow mealworm \\
\hline Tribolium confusum & Confused flour beetle \\
\hline Trogoderma inclusum & Large cabinet beetle \\
\hline
\end{tabular}

$\mathrm{N}_{2}$ fixing bacteria, especially members of Clostridia, Spirochaetes and gram-negative protoeobacteria including members of genera Desulfovibrio, Enterobacter and Rhizobiahave a large phylogenic diversity of nitrogenase reductase (nifH) genes in xylophagous termite guts (Breznak, 2002; Frohlich et al., 2007; Ngugi and Brune, 2011). The termite gut is ideal for denitrification activities such as $\mathrm{N}_{2} \mathrm{O}$ to $\mathrm{N}_{2}$ (Braker, 2011), because its gut constitutes a specific microhabitat with both physical and chemical conditions like an alkaline pH with oxygen and hydrogen gradients (Brune et al., 1995). Garba et al. (2011) found that the soil amended with termite mound soils resulted in better plant height, as well as an increase in leave number, fruits, and dry matter than those plants grown on unamended soil in fields under the cultivation of Solanum lycopersicum. Miyagawa et al. (2011) concluded that termite improved the growth of Oryza sativa L., and Phaseolus vulgaris L. Batalha et al. (1995) noted that combined use of $200 \mathrm{~g}$ of termite mound material with NPK led to a substantial increase in Solatium melongena production. Watson (1977) reported that Lolium perenne gave higher dry-matter yields with substrates derived from termite mounds than the comparable soil. Bama and Ravindran (2018) concluded that combined use of termite mound materials and inorganic fertilization significantly increase the Zea mays growth and yield. Kisa et al. (2006) showed that termite mound materials consisting of Pseudomonas monteilii species enhanced the ectomycorrhizal development between Acacia holosericea and Scleroderma dictyosporum. Suzuku et al. (2007) observed that combining sandy soil with termite mound materials at a proportion of $120 \mathrm{Mg} / \mathrm{ha}$ improved porosity and transformed the pore size distribution, thus causing a stepping up in the obtainable water content for the crop growth. 


\section{Archaea}

Soils in all terrestrial ecosystems are habitat of broad diversity of bacteria, archaea, fungi, annelids, insects as well as plants and algae. Archea is the smallest independently living, single-celled organisms on the earth, and it requires carbon to provide the building blocks for cell materials, as archeae are distributed in many environments such as soil (Aisalbie and Deslippe, 2013). Archea was considered as extremophile bacteria until it was introduced as the third domain of life by Woese and Fox (1977). Archaea plays an important impact in the global geochemical cycles in the world, because it constitutes a principle proportion of the microbial biomass (Offreet al., 2013). The methanogenic Archaea bring a broadened viewpoint to the field of nitrogen fixation, and at least which also found in diazotrophic methanogens present in Bacteria (nifH, D, K,E,Nand $X)$, besides, most nitrogenase in methanogens are belong to the molybdenum type (Leigh, 2000). The Archea differences with bacteria are in having isoprene lipids conjugated by ether bonds to glycerol-1-phosphate in their membranes, they lack peptidoglycan in their cell walls, and also their informational proteins are more similar to eukaryotes than to bacteria (Spang et al., 2017). Zhao et al. (2020) concluded that the functional genes of the archaeal community were mostly involved in nitrogen cycles, and it has principal role in biological soil cruts. The most important soil microbes' roles in soil ecosystems are physical support, raw materials, growth medium for plants, buffering water flows, nutrient cycling, recycling of wastes and detoxification, filtering of contaminants, habitat for biodiversity, biological control of pests, weeds and pathogens, carbon storage and regulation of green house gas emissions (Dominatiet al., 2010). The reduction of atmospheric nitrogen gas to ammonium just happened by existence of bacteria and archaea (Aislabie and Deslippe, 2013). Three kingdoms of Archaeaon the basis of phylogenetically divisions are presented in Table 9. Nitrogen fixing species in the Archaea is shown in Table 10. General characteristics of methanogenic Archaea are shown in Table 11. Distribution and phylogenetic affiliation of nonextremophilicArchaea is shown in Table 12. 
Table 9. Three kingdoms of Archaea on the basis of phylogenetically divisions (Barns et al., 1996; Luo and Wasserfallen, 2001; Reysenbach et al., 2000)

1- The Crenarchaeota which comprise most of the hyperthermophiles including the hyperthermophilic genera

Thermoproteus and Pyrodictium as well as the thermoacidophilic genera Sulfolobus, Acidianus and Desulfurococcus.

2- The Euryarchaeota, a phenotypically more diverse collection of microorganisms including the hyperthermophilic genera Thermoplasma, Thermococcus and the sulfate-reducing Archaeoglobus, the extreme halophiles, the strictly anaerobic methanogens.

3- The Korarchaeota, which are momentarily represented by several, as yet uncultured species.

Table 10. Nitrogen fixing species in the Archaea (Leigh, 2000)

\begin{tabular}{|l|c|}
\hline \multirow{2}{*}{ Methanococcales } & Methanococcus thermolithotrophicus \\
\cline { 2 - 2 } Methanomicrobiales & Methanococcus maripaludis \\
\cline { 2 - 2 } & Methanosarcina barkeri \\
\hline Methanobacteriales & Methanospirilum hungatei \\
\hline
\end{tabular}

Table 11. General characteristics of methanogenic Archaea

\begin{tabular}{|c|c|c|c|}
\hline Order Genus & Morphology & Substrates & Temperature $\left({ }^{\circ} \mathrm{C}\right)$ \\
\hline \multicolumn{4}{|l|}{ Methanobacteriales } \\
\hline Methanobacterium & Long rods & $\mathrm{H}_{2}+\mathrm{CO}_{2}$, formate & $35-40$ \\
\hline Methanobrevibacter & Short rods & $\mathrm{H}_{2}+\mathrm{CO}_{2}$, formate & $30-38$ \\
\hline Methanosphaera & Cocci & $\begin{array}{c}\text { Methanol+ } \mathrm{H}_{2} \text { (both } \\
\text { needed) }\end{array}$ & $36-40$ \\
\hline Methanothermus & Rods & $\mathrm{H}_{2}+\mathrm{CO}_{2}$ & $83-88$ \\
\hline \multicolumn{4}{|l|}{ Methanococcales } \\
\hline $\begin{array}{l}\text { Methanococcus } \\
\text { (medsophilicsp.) }\end{array}$ & Irregular cocci & $\begin{array}{c}\mathrm{H}_{2}+\mathrm{CO}_{2}, \text { pyruvate }+\mathrm{CO}_{2}, \\
\text { formate }\end{array}$ & $35-40$ \\
\hline $\begin{array}{l}\text { Methanococcus } \\
\text { (thermophilic sp.) }\end{array}$ & Irregular cocci & $\mathrm{H}_{2}+\mathrm{CO}_{2}$ & 88 \\
\hline \multicolumn{4}{|l|}{ Methanomicrobiales } \\
\hline Methanomicrobium & Short rods & $\mathrm{H}_{2}+\mathrm{CO}_{2}$, formate & 40 \\
\hline Methanogenium & Irregular cocci & $\mathrm{H}_{2}+\mathrm{CO}_{2}$, formate & $30-57$ \\
\hline Methanospirillum & Spirilla & $\mathrm{H}_{2}+\mathrm{CO}_{2}$, formate & $30-40$ \\
\hline Methanoplanus & Plate-shaped cells & $\mathrm{H}_{2}+\mathrm{CO}_{2}$, formate & $32-40$ \\
\hline Methanoculleus & Coccus & $\mathrm{H}_{2}+\mathrm{CO}_{2}$, formate & $37-60$ \\
\hline \multicolumn{4}{|l|}{ Methanosarcinales } \\
\hline Methanosarcina & $\begin{array}{c}\text { Large irregular cocci in } \\
\text { packets }\end{array}$ & $\begin{array}{l}\mathrm{H}_{2}+\mathrm{CO}_{2}, \text { methanol, } \\
\text { methylamines, acetate }\end{array}$ & $35-50$ \\
\hline Methanolobus & $\begin{array}{l}\text { Irregular cocci in } \\
\text { aggregates }\end{array}$ & Methanol, methylamines & $30-40$ \\
\hline Methanohalobium & Irregular cocci & Methanol, methylamines & 50 \\
\hline Methanococcoides & Irregular cocci & Methanol, methylamines & $23-35$ \\
\hline Methanohalophilus & Irregular cocci & $\begin{array}{c}\text { Methanol, methylamines, } \\
\text { methyl sulfides }\end{array}$ & $26-36$ \\
\hline Methanothrix & Long rods to filaments & Acetate & $35-60$ \\
\hline \multicolumn{4}{|l|}{ Methanopyrales } \\
\hline Methanopyrus & Rods in chains & $\mathrm{H}_{2}+\mathrm{CO}_{2}$ & 100 \\
\hline
\end{tabular}


Table 12. Distribution and phylogenetic affiliation of nonextremophilic Archaea

\begin{tabular}{|l|c|}
\hline \multicolumn{1}{|c|}{ Distribution } & Phylogenetic affiliation \\
\hline Marine Habitats & Crenarchaeota, Euryarchaeota \\
\hline Surface and deep waters (up to $3000 \mathrm{~m})$ & Crenarchaeota, Euryarchaeota \\
\hline Temperate coastal sediments $(12 \mathrm{~m})$ & Crenarchaeota, Euryarchaeota \\
\hline Low-temperature deep-sea sediments $(1500$ to $4500 \mathrm{~m})$ & Crenarchaeota, Euryarchaeota \\
\hline Temperate microbial mats at deep-sea hydrothermal vent & Crenarchaeota, Euryarchaeota \\
\hline Antarctic low-temperature surface waters & Euryarchaeota \\
\hline Salt marsh & \\
\hline & \\
\hline Associated with Marine Metazoans & Crenarchaeota \\
\hline $\begin{array}{l}\text { Gut of abyssal holothurians Oneirophantamutabilis } \\
\text { (4870 m) }\end{array}$ & Crenarchaeota, Euryarchaeota \\
\hline Digestive tract of fish & Crenarchaeon, Crenarchaeota symbiosum \\
\hline Tissues of sponge Axinella Mexicana (10-20 m) & \\
\hline & Crenarchaeota, Euryarchaeota \\
\hline Freshwater Habitats & Crenarchaeota, Euryarchaeota \\
\hline Lake sediments & Crenarchaeota \\
\hline & Crenarchaeota, Euryarchaeota \\
\hline Terrestrial Habitats & Crenarchaeota, Euryarchaeota \\
\hline Soils & \\
\hline Subsurface paleosol (188 m) & \\
\hline Contaminated aquifer & \\
\hline Rice roots & \\
\hline
\end{tabular}

\section{Fungi}

The legumes-Rhizobium symbiosis is the most efficacious system for nitrogen fixation, the bacteria will interact with leguminous plant in the host specific way and form nitrogen fixing root bacteria (Volpin and Kapunik, 1994; de Fariaet al., 2010). The positive effects of Arbuscular mycorrhizal (AM) fungi such as growth promotion, increased root length, leaf area, stem diameter, transplant performance and tolerance to stresses have been reported previously (Gohre and Pazkowski, 2006; Guether et al., 2009; Kafkas and Ortas, 2009; Sharma et al., 2009: Kiers et al., 2011; Sharma et al., 2011; Sharma et al., 2012). AM fungi are vital in ecological agriculture, and they generally characterized by short life cycles of arbuscules and also frequent and rapid colonization of new roots and the emergence of vesicles in the oldest colonizing units (Alexander et al., 1988; Smith and Read, 1997; Azcon-Aguilar et al., 2002; Singh and Adholeya, 2004). Volpin and Kalpunik (1994) described that Glycine max, Pisum sativum, Medicago sativa, Cicer arietinum, Psophocarpus tetragonolobus inoculated with Azospirillum and Rhizobium showed increase in early nodulation, enhancement nodule on main root, total nodule number, nodule weight and nodule specific activity in nitrogen fixation process. Ingraffia et al. (2019) proved the role of Arbuscular mycorrhizal fungi (AMF) in driving biological interactions amongst neighboring plants as they are obligate soil biotrophs (Guisande-Collazo et al., 2016). Two main endosymbioses for legume plants are a) with soil fungi, forming phosphorus acquiring arbuscular mycorrhiza, and $b$ ) with nitrogen-fixing bacteria leading to the formation of nitrogen-fixing root nodules (Manchanda and Garg, 2007). One of the most characteristic of mycorrhizal symbiosis is improving root nodulation and $\mathrm{N}_{2}$ fixation by boosting the uptake of main nutrients or affecting legume-Rhizobium symbiosis (Barea et al., 2005; Saia et al., 2014), and of course its significant influence on biological nitrogen fixation (Puschel et al., 2017). Xie et al. (2019) showed that P. liquidambaris promotes peanut nodulation and nitrogen fixation which is useful in building a sustainable agricultural system. Veselaj et al. (2018) concluded that the combination of application of Rhizobium leguminosarum and arbuscular mycorrhizae fungi is a sustain way to provide a 
significantly higher yield for non-saline plants. Bauer et al. (2012) found the importance of soil microbial communities because of impact of AMF and $\mathrm{N}_{2}$-fixers on both community structure and crop productivity.

\section{Azotobacter}

The Azotobacteriaceae consists of two genera which is Azomonas sp. and Azotobacter sp. Azotobacter has significant roles in availability of some nutritions like Nitrogen, Phosphorus, Sulphur and carbon via boosting mineralization of organic residues (Fekete et al., 1989; Levaiet al., 2008; Rojas-Tapias et al., 2013).Azotobactergenus belongs to the $\gamma$-subclass of the Proeobacteria (Tchan and New, 1984; Becking, 2004) which constitutes seven species namely, A. chroococcum, A. vinelandii, A. beijerinckii, A. paspali, $A$. armeniacus, A. nigricans, and $A$. salinestri (Jimenez et al., 2011). A. chroococcum is the most inhabitingvarious soils (Balandreau, 1986; Tchan and New, 1984; Dobereiner, 1995; Martyniuk and Martyniuk, 2003). These free-living aerobic bacteria found in soils dominantly, and its populations influenced by soil physic-chemical such as organic matter, $\mathrm{pH}$, temperature, soil moisture and depth and also microbiological interactions (Kizilkaya, 2009; Chowdhury-Paul et al., 2018; Nag et al., 2018). It is able to fix at least $10 \mathrm{mg} \mathrm{N}$ per gram of carbohydrate, and although, it is an obligate aerobic bacterium, is can grow under low $\mathrm{O}_{2}$ (Tejeraet al., 2005). It has been reported that Azotobacteria are much available in the rhizosphere of plants than in surrounding soil, and this abundance mostly depends of crop species (Sariv and Ragoviv, 1963; Garg et al., 2001; Aquilantiet al., 2004; Jnawaliet al., 2015; Inomuraet al., 2017; Rodrigues et al., 2018). Several studies have shown the microbial secretion of stimulating hormones, like auxins, cytokinins and gibberellins (Azcon and Barea, 1975; Martinez Toledo et al., 1989, Salmeron et al., 1990; Gonzales-Lopez et al., 1991). Azotobacter also benefit soil fertility by reducing the toxic level of soil accumulated phenolic acids (Gauri et al., 2012). Like A. paspaliwhich can be found just in the rhizosphere of a grass (Paspalum notantum), the occurrence of other Azotobacter species in more restricted in the environment (Tchan and New, 1984; Dobereiner, 1995). It was first described by Dobereiner and Pedrosa (1975). The increase in final yield of maize by Azotobacter inoculation because of nitrogen fixation has been reported (Mrkovacki and Milic, 2001; Waniet al., 2013). Azotobacteriaceae classification is presented in Table 13.

Table 13. Azotobacteriaceae classification

\begin{tabular}{|l|c|}
\hline \multicolumn{2}{|c|}{ Azotobacteriaceae } \\
\hline Azomonas sp. (non-cyst forming) & Azomona sagilis \\
\hline & Azomonas insignis \\
\hline & Azomonas macrocytogenes \\
\hline Azobacter sp. (cyst forming) & Azotobacter chroococcum \\
\hline & Azotobacter vinelandii \\
\hline & Azotobacter beijerinckii \\
\hline & Azotobacter nigricans \\
\hline & Azotobacter armeniacus \\
\hline & Azotobacter paspali \\
\hline
\end{tabular}

Azotobacter vinelandii is a gram-negative bacterium, capable of fixing nitrogen in various environments (Sadoff, 1975), and it used to consider as a model for different studies such as biochemical physiology and genetics (Dixon and Kahn, 2004; Yu and Ullrich, 2018). It is known to produce alginate under aerobic environment (Jarman, 1979; Horan et al., 1981; Annisonand Couperwhite, 1986; Clementi, 1997; McRose et al., 2019). A. vinelandii showed nearly constant respiration rates and insignifiacant decreases in nitrogen activity, even when $\mathrm{O}_{2}$ concentrations ranging from 30 to 100\% air saturation (Post et al., 1983; Boiardi, 1994; Liu et al., 2004). Sabra et al. (2000) suggested that the production of alginate, mainly capsule on the cell surface, 
forms a productive barrier for $\mathrm{O}_{2}$ transfer into the cell. Several studies have showed that Azotobacter strains could increase seed germination and primarily seedling growth (Shino Suzuki et al., 2002; Gholamiet al., 2009). Azotobacter sp. produces chemical substances which have been similar Gibberellic acid $\left(\mathrm{GA}_{3}\right)$, and 3-indole acetic acid (IAA) (Sivaskthi et al., 2017). Martinez-Toledo et al. (1985) reported that in natural habitats, where corn plants are not influenced by nitrogen stress, A. chroococcum could be of the main importance in production of stimulatory factors. Kizilkaya (2008) introduced A. chroococcum strains as the key way to achieve sustainable agricultural production of spring wheat. The important and effects of $A$. chroococcum strains and AM fungi on host plants have been reported in previous researches (Savenkovaet al., 1999; Kumar et al., 2006; Sharma and Kumar, 2008; Kumar and Sharma, 2009; Sharma et al., 2012; Dutt et al., 2013a,b; Khudhur and Askar, 2013; Sharma et al., 2014; Velmourouganeet al., 2019). It has been proved that $A$. chroococcum has been found to be the most efficacious in nitrogen fixing and also in phytohormone production (IAA) (Ravikumar et al., 2004). Romero-Perdomo et al. (2017) proved that Azotobacter chroococcum $\mathrm{AC} 1$ and $\mathrm{AC} 10$ showed a viable alternative to improve final cotton yield as well as lowering the nitrogen fertilizer dose and let to reduce the environmental deterioration connected with nitrogen pollution. Din et al. (2019) found that Aspergillus niger (A. niger) and Azotobacter may replace expensive and harmful chemical fertilizers with both eco-friendly and cost-effective biofertilizers. Mittal et al. (2011) reported that great benefits of $A$. chroococcum in nitrogen fixing for cotton crops in arid and semi-arid tropical regions. Aminpanah and Firouzi (2019) also found that inoculation of seeds with a combination of A. lipoferum and A. chroococcum, increase rice grain yield and a thousand grain weight. Application of Azospirillum spp. and Azotobacter spp. increased the growth and final yield of strawberry under hydroponic condition compare to the control treatment (Rueda et al., 2016). Azotobacter can be an appropriate option for nitrogen deman and best alternative to nitrogen fertilizer in wheat cultivation which may lead to higher productivity (Mahato and Kafle, 2018).

\section{Bacteria}

Nitrogen fixation by microbes also found in root sheaths of cereals and tropical grasses (Kirchhofet al., 1997; Gutierrez-Zamora and Martinez-Romero, 2001; Rosenblueth and Martinez-Romero, 2004; Patra et al., 2006; Chowdhury et al., 2007; Montanez et al., 2008 Bergmann et al.,2009; Davis et al., 2010; Burbanoet al., 2011; Sessitshet al., 2012; Vitouseket al., 2013; Ritchie and Raina, 2016). All grasses, especially C4 grasses show the highest potential for barboringdiaotrophs (James, 2000; Reis et al., 2001; Davis et al., 2010; Tresederet al., 2012). Biological nitrogen fixation in depends on different types of species (Marques et al., 2017; Barazettiet al., 2019). Muangthonget al. (2015) found that Novosphingobiumsediminicola and Ochrobactrum intermedium which were isolated form the leaves of chewing sugarcane plants are capable of to get significant nitrogen concentrations when growing in nitrogen free sand. Legume Nodulation Bacteria (LNB) divided into six general which are Agrobacterium, Rhizobium, Bradyrhizobium, Sinorhizobium, Burkholderia and Herbaspirillum (Mwangi et al., 2011). The genus Azospirillum, which belong to the family Rhodospirillaceae of the class Alphaproteobacteria, is known as a representative nitrogen fixing bacterium containing plantgrowth promoting properties (Bashan and de-Bashan, 2010), and almost all of them dwell in aquatic environments (Kwak and Shin,2016). Zhang et al. (2020) observed that nitrogen fixing bacteria can improve the quality of compost and may result in meaningful reduction in N- and C- losses. Bahulikaret al. (2014) reported that the most important nitrogen-fixing bacteria related to Switchgrass were Rhizobium and Methylobacterium species of the alphaproteobacteria, Burkholderia and Azoarcus species of the betaproteobacteria and Desulfuromona and Geobacter species of the deltaproteobacteria. Hara et al. (2019) found that the main important nitrogen fixing bacteria in sorghum roots are bradyrhizobia which resemble photosynthetic B. oligotrophicum S58 ${ }^{\mathrm{T}}$ and non-nodulatingBradyrhizobium sp. S23321. The unique role of Bradyrhizobium members have been reported in nitrogen fixation of sugarcane (Thaweenutet al., 2011; Fischer et al., 2012; Rosenbluethet al., 2018), and sweet potato (Terakado-Tonookaet al., 2008). Zhang et al. (2020) 
noted that the higher $\mathrm{C} / \mathrm{N}$ promote the relative abundance of nitrogen fixing bacteria like Thermoactinomyces, Planifilum, Flavobacterium, Bacillaceae, Pseudomonas, Sphingobacterium, Paenibacillus, Bacillus and Thermobifida. Meaningful influence of both arbuscular mycorrhizal fungi (AMF) and $\mathrm{N}_{2}$-fixer on crop production and community structure which has proved the essential role of soil microbial communities (Xiao et al., 2010; Bauer et al., 2012; Goss and de Varennes, 2012; Abd-Allaet al., 2014; Mbarkiet al., 2017; Hu et al., 2019; Thioubet al., 2019; Xu et al., 2019; Massa et al., 2020). AMF biofertilizer usage can increase continuous cropping of American ginseng growth by boosting the AMF inoculation rate, promoting plant-uptake of essential elements such as nitrogen and phosphorus and by increasing soil-borne pathogens (Johnson, 2010; Smith et al., 2011; Bucking and Kafle, 2015; Liu et al., 2020). Arbuscular mycorrhizal fungi is also beneficial to ameliorate the negative effects of a stressful environment (Levy et al., 1983; Goicoechea et al., 2005; Jebaraet al., 2010; Ruiz-Lozano et al., 2012; Garg and Pandey, 2016; Li et al., 2016; Verzeaux et al., 2017; Zhang et al., 2019). It has been proved that AMF can influence plant competition interaction between cooccurring plant species which may represent the vital role of mycorrhizal symbionts for sustainable crop management strategies (Raimam et al., 2007; Nafadyet al., 2018; Bahadur et al., 2019). The most important nitrogen fixing bacteria is shown in Table 14. Association of cereals and nitrogen-fixing PGPR are shown in Table 15.

Table 14. The most important nitrogen fixing bacteria (La Rue,1977)

\begin{tabular}{|l|c|}
\hline \multicolumn{1}{|c|}{ Family } & Genera \\
\hline Thiorhodaceae (Chromatiaceae) & Thiocapsa, Chromatium \\
\hline Athiorhodaceae (Rhodospirillaceae) & Rhodospirillum, Rhodopseumonas \\
\hline Hyphomicrobiaceae & Rhodomicrobium \\
\hline Chlorobacteriaceae & Chlorobium \\
\hline Spirillaceae & Desulfovibrio, Desulfotomaculum \\
\hline Azotobacteriaceae & Azotobacter, Beijerinckii, Derxii \\
\hline Entrobacteriaceae & Klebsiella, Escherichia, Enterobacter \\
\hline Corynebacteriaceae & Corynebacterium \\
\hline Bacillaceae & Bacillus, Clostridium \\
\hline
\end{tabular}

Table 15. Association of cereals and nitrogen-fixing PGPR (Santi et al., 2013)

\begin{tabular}{|c|c|}
\hline+2 & Diazotroph inoculants \\
\hline \multirow{3}{*}{ Wheat } & H. seropedicae \\
\hline & Azospirillum sp. \\
\hline & Azotobacter sp. \\
\hline \multirow{2}{*}{ Maize } & Burkholderia sp. \\
\hline & Azospirillumbrasilense \\
\hline \multirow{6}{*}{ Rice } & Azoarcus \\
\hline & Burkholderia \\
\hline & A. vietnamiensis \\
\hline & Gluconacetobacterdiazotrophicus \\
\hline & Herbaspirillumseropedicae \\
\hline & Serratia marcescens \\
\hline
\end{tabular}




\section{Conclusions}

Nitrogen availability often restricts biological productivity in ecosystems. Nitrogen is the most important element for all forms of life, because it is found in nucleic acids, proteins and chlorophyll, and all forms of live bacteria, fungi, green plants and animals of all kinds can not grow and work unless they get nitrogen in an acceptable form. The sole usage of chemical fertilizer, especially nitrogen may have many unfavorable impacts on not only human and environmental health, but also on green house gasses and negative influence on the ozone layer. Nitrogen gas is abundant, but unreachable to majority of organisms. Nitrogen fixation involves formation of ammonium from $\mathrm{N}_{2}$, which needs a high input of energy. Biological nitrogen fixation utilizes the enzyme nitrogenase and ATP to fix nitrogen. Nitrogenase contains a Fe-protein and a MoFe-protein and other metal cofactors. Soil diazotrophs possess the function of fixing atmospheric $\mathrm{N}_{2}$ into biologically available ammonium in ecosystems. In Aechaea, nitrogen fixation has been reported in some methanogens such as Methanobacteriales, Methanococcales, and Methanosarcinales. Within Bacteria, nitrogen fixation is much more extensively distributed and has been seed in phyla Actinobacteria, Bacteroidetes, Cyanobacteria, Chlorobi, Chloroflexi, Firmicutes, and Proteobacteria. niffH is the gene that encodes the nitrogenase which is the major structural protein that catalyzes the $\mathrm{N}_{2}$ fixation reaction. The most important requirements for nitrogen fixation is a nitrogenase enzyme system, a source of adenosive triphosphate (ATP), a source of reducing power, a protective system for the enzyme from oxygen inactivation, and the rapid removal of nitrogen fixed from the site of nitrogen-fixation to prevent inhibition of the nitrogenase. The key element to improve environmental sustainability is recognizing the importance to improve the biophysical systems which support both short and long-term quality of all aspects of life on the earth with complete understanding of both health and diversity of natural ecosystems. Termite and its bacteria may lead to increase the soil fertility, improved plant growth, increased final crop yield and promote both better health and healthy environment. While, application of chemical fertilizer may lead to soil degradation and reduced crop yield which are the main reason of starvation. In all tropical and subtropical biomes, termites have a leading role in nitrogen mineralization. Two kinds of termites namely soil-feeding and humus-feeding termites normally thrive on nitrogen in soil substances, while, grass- and weed-feeding termites depend on the symbiotic bacterial communities in their gut for biological nitrogen fixation. The utilize of Azotobacter sp. presents a sustainable way to replace chemical fertilizer and even pesticides, which may lead to lower production cost, increase the productivity, reducing environmental pollution in the agricultural systems which heavily depend on chemical fertilizer and pesticides. This important bacterium is an obligate aerobic which can also grow in low $\mathrm{O}_{2}$ situation. The most important ecological parameters which affect the spreading of termites are mean annual rainfall, mean number of rain days, atmospheric humidity and temperature, altitude, vegetation, soil type natural enemies and other related organisms. To have sustainable agriculture, replacing expensive chemical nitrogen fertilizers with environmentally friendly ways is the most accepted practice.

\section{Authors' Contributions}

All authors read and approved the final manuscript.

\section{Acknowledgements}

This work was supported by the National Key R\&D Program of China (Research grant 2019YFA0904700). 


\section{Conflict of Interests}

The authors declare that there are no conflicts of interest related to this article.

\section{References}

Abd-Alla MH, El-Enany AWE, Nafady NA, Khalaf DM, Morsy FM (2014). Synergistic interaction of Rhizobium leguminosarum bv. viciae and arbuscular mycorrhizal fungi as a plant growth promoting biofertilizers for faba bean (Vicia faba L.) in alkaline soil. Microbiological Research 169:49-58. https://doi.org/10.1016/j.micres.2013.07.007

Abdollahi M, Soleymani A, Shahrajabian MH (2018). Evaluation of yield and some of physiological indices of potato cultivars in relation to chemical, biological and manure fertilizers. Cercetari Agronomice in Moldova 51(2):53-66. https://doi.org/10.2478/cerce-2018-0016

Aislabie J, Deslippe JR (2013). Soil microbes and their contribution to soil services. Soil microbes and their contribution to soil service. In: Dymond JR (Ed). Ecosystem Services in New Zealand- cCnditions and Trends. Mannaki Whenua Press, Lincoln, New Zealand.

Alexander T, Toth R, Meier R, Weber HC (1988). Dynamics of arbuscule development and degeneration in onion, bean and tomato with references to vesicular-arbuscular mycorrhizal in grasses. Canadian Journal of Botany 67:25052513. https://doi.org/10.1139/b89-320

Allen ON, Allen EK (1981). The Leguminosae. University of Wisconsin Press, Madison, WI, pp 812. https://doi.org/10.1002/fedr.4910950119

Aminpanah H, Firouzi S (2019). Fertilizer management using plant growth-promoting rhizobacteria in rice fields. International Journal of Agricultural Management and Development 9(1):67-76.

Annison G, Couperwhite I (1986). Effect of limiting substrate concentration, growth rate and aeration on alginate composition and production by Azotobacter vinelandii in continuous culture. Food Hydrocoll 1:101-111. https://doi.org/10.1016/s0268-005x(86)80012-1

Aquilianti L, Favilli F, Clementi F (2004). Comparison of different strategies for isolation and preliminary identification of Azotobacter from soil samples. Soil Biology and Biochemistry 36:1475-1483. https://doi.org/10.1016/j.soilbio.2004.04.024

Argandona M, Fernandez-Carazo R, Llamas I, Martinez-Checa F, Caba JM, Quesada E, Moral AD (2005). The moderately halophilic bacterium Halomonas maura is a free-living diazotroph. FEMS Microbiol Letters 244:6974. https://doi.org/10.1016/j.femsle.2005.01.019

Azcon R, Barea JM (1975). Synthesis of auxins, gibberellins and cytokinins by Azotobacter vinelandii and Azotobacter beijerinckii related to effects produced on tomato plants. Plant and Soil 43:609-619. https://doi.org/10.1007/bf01928522

Azcon-Aguilar C, Jaizme-Vega MC, Calvet C (2002). The contribution of arbuscular mycorrhizal fungi to the control of soil-borne plant pathogen. In: Gianinazzi S, Schuepp H, Barea JM, Haselwandter K (Eds). Mycorrhizal Technology in Agriculture: From Genes to Bioproducts. Birkhauser Verlag AG, Basel, Switzerland, pp 187-197. https://doi.org/10.1007/978-3-0348-8117-3-15

Bahadur A, Jin Z, Long X, Jiang S, Zhang Q, Pan J, ... Feng H (2019). Arbuscular mycorrhizal fungi alter plant interspecific interaction under nitrogen fertilization. European Journal of Soil Biology 93:103094. http://doi.org/10.1016/j.ejsobi.2019.103094

Bahulikar RA, Torres-Jerez I, WorleyE, Craven K, Udvardi MK (2014). Diversity of nitrogen-fixing bacteria associated with Switchgrass in the native tallgrass praire of Northern Oklahoma. Applied and Environmental Microbiology 80(18):5636-5643. https://doi.org/10.1128/aem.02091-14

Balandreau J (1986). Ecological factors and adaptive process in $\mathrm{N}_{2}$-fixing bacterial populations of the plant environment. Plant and Soil 90:73. https://doi.org/10.1007/bfo2277388

Bama PS, Ravindran AD (2018). Influence of combined termite mound materials and inorganic fertilizers on growth parameters of maize under non sterilized pot culture study. Elixir Applied Zoology 125:52303-52305. 
Barea JM, Werner D, Azcon-Guilar C, Azcon R (2005). Interactions of arbuscular mycorrhiza and nitrogen fixing symbiosis in sustainable agriculture. In: Nitrogen Fixation in Agriculture, Forestry, Ecology, and the Environment. Dordrecht: Springer, pp 199-222. https://doi.org/10.1007/1-4020-3544-6-10

Barns SM, Delwiche CF, Palmer JD, Pace NR (1996). Perspectives on archaeal diversity, thermophily and monophyly from environmental rRNA sequences. Proceedings of the National Academy of Sciences of the USA 93:91889193. https://doi.org/10.1073.pmas.93.17.9188

Barazetti AR, Simionato AS, Navarro MOP, dos Santos IMO, Modolon F, de Lima Andreata MF, ... Andrade G (2019). Formulations of arbuscular mycorrhizal fungi inoculums applied to soybean and corn plants under controlled and field conditions. Applied Soil Ecology 142:25-33. https://doi.org/10.1016/j.apsoil.2019.05.015

Bashan Y, De-Bashan LE (2010). How the plant growth-promoting bacterium Azospirillum promotes plant growth- a critical assessment. Advances in Agronomy 108:77-136. https://doi.org/10.1016/s0065-2113(10)08002-8

Batalha L, Da Silva Filho D, Martius C (1995). Using termite nests as a source of organic matter in agrosilvicultural production systems in Amazonia. Scientia Agricola 52:318-325. https://doi.org/10.1590/s010390161995000200019

Bauer JT, Kleczewski NM, Bever JD, Clay K, Reynolds HL (2012). Nitrogen-fixing bacteria, arbuscular mycorrhizal fungi, and the productivity and structure of prairie grassland communities. Oecologia 170:1089-1098. https://doi.org/10.1007/s00442-012-236-3

Becking J (2006). The family Azotobacteraceae. Prokaryotes 6:759-783. https://doi.org/10.1007/0-387-30746-X-26

Bellenger JP, Xu Y, Zhang X, Morel FMM, Kraepiel AML (2014). Possible contribution of alternative nitrogenase to nitrogen fixation by asymbiotic $\mathrm{N}_{2}$-fixing bacteria in soils. Soil Biology and Biochemistry 69:413-420. https://doi.org/10.1016/j.soilbio.2013.11.015

Benavides M, Aristegui J, Agawin NSR, Alvarez-Salgado XA, Alvarez M, Troupin C (2013). Low contribution of $\mathrm{N}_{2}$ fixation to new production and excess nitrogen in the subtropical northeast Atlantic margin. Deep-Sea Research I 81:36-48. https://doi.org/10.1016/j.dsr.2013.07.004

Benndorf R, Guo H, Sommerwerk E, Weigel C, Garcia-Altares M, Martin K, ... Poulsen M (2018). Natural products from actinobacteria associated with fungus-growing termites. Antibiotics 7:83. https://doi.org/10.3390/antibiotics7030083

Bentley BL (1984). Nitrogen fixation in termites: fate of newly fixed nitrogen. Journal of Insect Physiology 40:653-655. https://doi.org/10.1016/0022-1910(84)90050-7

Bergmann D, Zehfus M, Zierer L, Smith B, Gabel M (2009). Grass rhizosheaths: associated bacterial communities and potential for nitrogen fixation. Western North American Naturalist 69:105-114. https://doi.org/10.3398/064.069.0102

Betancourt DA, Loveless TM, Brown JW, Bishop PE (2008). Characterization of diazotrophs containing Moindependent nitrogenase, isolated from diverse natural environments. Applied and Environmntal Microbiology 74:3471-3480. https://doi.org/10.1128/aem.02694-07

Bignell DE (2000). Introduction to symbiosis. In: Abe T, Bignell DE, Higashi M (Eds). Termites: Evolution, Sociality, Symbioses, Ecology. Dordrecht, Springer, pp 189-208. https://doi.org/10.1007/978-94-017-3223-9-9

Bishop PE, Premakumar R, Dean DR, Jacobson MR, Chnisnell JR, Rizzo TM, Kopczynski J (1986). Nitrogen fixation by Azotobacter vinelandii strains having deletions in structural genes for nitrogenase. Science 232:92-94. https://doi.org/10.1126/science.232.4746.92

Bishop PE, Premakumar R (1992). Alternative nitrogen fixation systems. In: Stacey G, Burris RH, Evans DJ (Eds). Biological Nitrogen Fixation. Chapman \& Hall, New York, pp 736-762.

Biswas B, Gresshoff PM (2014). The role of symbiotic nitrogen fixation in sustainable production of biofuels. International Journal of Molecular Sciences 15:7380-7397. https://doi.org/10.3390/ijms15057380

Boiardi JL (1994). Metabolic cost of nitrogen incorporation by $\mathrm{N}_{2}$-fixing Azotobacter vinelandii is affected by the culture pH. Biotechnology Letters 16:1195-1198. https://doi.org/10.1007/bfo1020850

Boyd ES, Peters JW (2013). New insights into the evolutionary history of biological nitrogen fixation. Frontiers in Microbiology 4:201. https://doi.org/10.3389/fmicb.2013.00201

Braker G, Conrad R (2011). Diversity, structure and size of $\mathrm{N}_{2} \mathrm{O}$-producing microbial communities in soils-what matters for their functioning? In: Allen SS, Laskin I, Geoffrey MG (Eds). Advances in Applied Microbiology. Academic Press, Chapter 2, pp 33-70. https://doi.org/10.1016/b978-0-12-387046-9.00002-5 
Brauman A (2000). Effect of gut transit and mound deposit on soil organic matter transformation in the soil feeding termite: a review. European Journal of Soil Biology 36:117-125. https://doi.org/10.1016/s1164-5563(00)01058$x$

Brauman A, Majeed MZ, Buatois B, Robert A, Pablo AL, Miambi (2015). Nitrous oxide $\left(\mathrm{N}_{2} \mathrm{O}\right)$ emissions by termites: does the feeding guild matter? PLoS One 10(12):e01443440. https://doi.org/10.1371/journal.pone.0144340

Breznak JA, Brill WJ, Mertins JW, Coppel HC (1973). Nitrogen fixation in termites. Nature 244:577-580.

Breznak JA (2002). Phylogenetic diversity and physiology of termite gut spirochetes. Integrative and Comparative Biology 42:313-319. https://doi.org/10.1093/icb/42.2.313

Broumand P, Rezaei A, Soleymani A, Shahrajabian MH, Noory A (2010). Influence of forage clipping and top dressing of nitrogen fertilizer on grain yield of cereal crops in dual purpose cultivation system. Research on Crops 11(3):603-613. https://doi.org/10.2134/agronj2015.0447

Bru D, Ramette A, Saby NP, Dequiedt S, Ranjard L, Jolivet C, ... Philippot L (2011) Determinants of the distribution of nitrogen-cycling microbial communities at the landscape scale. ISME Journal 5:532-542. https://doi.org/10.1038/ismej.2010.130

Brune A, Emerson D, Breznak JA (1995). The termite gut microflora as an oxygen sink - microelectrode determination of oxygen and $\mathrm{pH}$ gradients in guts of lower and higher termites. Applied and Environmental Microbiology 61:2681-2687. https://doi.org/10.1128/aem.61.7.2681.1995

Brune A, Ohkuma M (2010). Role of the termite gut microbiota in symbiotic digestion. In: Bignell DE, Roisin Y, Lo N (Eds). Biology of Termites: a Modern Synthesis. Dordrecht, Springer, pp 439-475. https://doi.org/10.1007/97890-481-3977-4-16

Bucking H, Kafle A (2015). Role of arbusuclar mycorrhizal fungi in the nitrogen uptake of plants: current knowledge and research gaps. Agronomy 5:587-612. https://doi.org/10.3390/agronomy5040587

Burbano CS, Liu Y, Rosner KL, Reis VM, Caballero-Mellado J, Rein-hold-Hurek B, Hurek T (2011). Predominant nifH transcript phylotypes related to Rhizobium rosettiformans in field-grown sugarcane plants and in Norway spruce. Environmental Microbiology Reports 3:383-389. https://doi.org/10.1111/j.1758-2229-2010.00238.x

Capone DG, Zehr JP, Paerl HW, Bergman B, Carpenter EJ (1997). Trichodesmium, a globally significant marine cyanobacterium. Science 276:1221-1229. https://doi.org/10.1126/science.276.5316.1221

Chain P, Lamerdin J, Larimer F, Regala W, Lao V, Land M, ... Arp D (2003). Complete genome sequence of the ammoniaoxidizing bacterium and obligate chemolithoautotrophy Nitrosomonas europaea. Journal of Bacteriology 185:2759-2773. https://doi.org/10.1128/jb.185.9.2759-2773.2003

Che R, Deng Y, Wang F, Wang W, Xu Z, Hao Y, ... Cui X (2018). Autotrophic and symbiotic diacotrophs dominate nitrogen-fixing communities in Tibetan grassland soils. Science of Total Environment 639:997-1006. https://doi.org/10.1016/j.scitotenv.2018.05.238

Chen Y-LL, Chen H-Y, Lin Y-H, Yong T-C, Taniuchi Y, Tuo S-H (2014). The relative contributions of unicellular and filamentous diazotrophs to $\mathrm{N}_{2}$ fixation in the South China Sea and the upstream Kuroshio. Deep-Sea Research I 85:56-71. https://doi.org/10.1016/j.dsr.2013.11.006

Chen T-Y, ChenY-LL, Sheu D-S, Chen H-Y, Lin Y-H, Shiozaki T (2019). Community and abundance of heterotrophic diazotrophs in the northern South China Sea: revealing the potential importance of a new alphaproteobacterium in $\mathrm{N}_{2}$ fixation. Deep-Sea Research Part I 143:104-114. https://doi.org/10.1016/j.dsr.2018.11.006

Chien YT, Zinder SH (1994). Cloning, DNA-sequencing, and characterization of a nifD-homologous gene from the archaeon methanosaticina barkeri-227 which resembles nifD from the eubacterium Clostridium pasteurianum. Journal of Bacteriology 176:6590-6598. https://doi.org/10.1016/j.dsr.1994.06.001

Chisnell JR, Premakumar R, Bishop PE (1988). Purification of the second alternative nitrogenase from a niffHD deletion strain of Azotobacter vinelandii. Journal of Bacteriology 170:27-33. https://doi.org/10.1128/jb.170.1.27-33.1988

Chowdhury SP, Schmid M, Hartmann A, Tripathi AK (2007). Identification of diazotrophs in the culturable bacterial community associated with roots of Lasiurus sindicus a perennial grass of thar desert, India. Microbil Ecology 54:82-90. https://doi.org/10.1007/s00248-006-9174-1

Chowdhury-Paul S, Pando-Robles V, Jimenez-Jacinto V, Segura D, Espin G, Nunez C (2018). Proteomic analysis revealed proteins induced upon Azotobacter vinelandii encystment. Journal of Proteomics181:47-59. https://doi.org/10.1016/j.jprot.2018.03.031

Clement F (1997). Alginate production by Azotobacter vinelandii. Critical Reviews in Biotechnology 17:327-361. https://doi.org/10.3109/07388559709146618 
Cotta SR, Dias ACF, Marriel IE, Andreote FD, Seldin L, Elsas JFV (2014). Different effects of transgenic maize and nontransgenic maize on nitrogen-transforming archaea and bacteria in tropical soils. Applied and Environmental Microbiology 80(20):6437-6445. https://doi.org/10.1128/aem.01778-14

Curtis AD, Waller DA (1998). Seasonal patterns of nitrogen fixation in termites. Functional Ecology 12:803-807. https://doi.org/10.1046/j.1365-2435.1998.00248.x

Davis SC, Parton WJ, Dohleman FG, Smith CM, Del Grosso S, Kent AD, DeLucia EH (2010). Comparative biogeochemical cycles of bioenergy crops reveal nitrogen-fixation and low greenhouse gas emissions in a Miscanthus giganteusagro-ecossytem. Ecosystems 13:144-156. https://doi.org/10.1007/s10021-009-9306-9

Dawes TZ (2010). Reestablishment of ecological functioning by mulching and termite invasion in a degraded soil in an Australian savanna. Soil Biology and Biochemistry 42:1825-1834. https://doi.org/10.1016/j.soilbio.2010.06.023

De Faria SM, Diedhiou AG, Lima HC, Ribeiro RD, Galiana A, Castilho AF, Henriques C (2010). Evaluation the nodulation status of leguminous species from the Amazonian forest of Brazil. Journal of Experimental Botany 62:3119-3127. https://doi.org/10.1093/jxb/erq142

Dent D, Cocking E (2017). Establishing symbiotic nitrogen fixation in cereals and other non-legume crops: The Greener Nitrogen Revolution. Agricultura and Food Security 6:7. https://doi.org/10.1186/s40066-016-0084-2

Devi R, Thakur R (2018). Screening and identification of bacteria for growth promoting traits from termite mound soil. Journal of Pharmacognosy and Phytocemistry 7:1681-1686.

Din M, Nelofer R, Salman M, Abdullah FH, Khan, Khan A, Ahmad M, Jalil F, Din JU, Khan M (2019). Production of nitrogen fixing Azotobacter (SR-\$) and phosphorus solubilizing Aspergillus niger and their evaluation on Lagenaria siceraria and Abelmoschus esculentus. Biotechnology Reports 22:e00323. https://doi.org/10.1016/j.btre.2019.e00323

Dixon R, Kahn D (2004). Genetic regulation of biological nitrogen fixation. Nature Reviews Microbiology 2:621. https://doi.org/10.1038/nrmicro854

Dobereiner J, Day JM (1975). Nitrogen fixation in rhizosphere of grasses. In: Stewart WDP (Ed). Nitrogen Fixation by Free-Living Microorganisms. Cambridge University Press, pp 39-56.

Dobereiner J (1995). Isolation and identification of aerobic nitrogen-fixing bacteria from soil and plants. In: Alef K, Nannipieri P (Eds). Methods in Applied Soil Microbiology and Biochemistry, Academic Press, London, pp 134141.

Dominati E, Patterson M, MacKay A (2010). A framework for classifying and quantifying natural capital and ecosystem services of soils. Ecological Economics 69:1858-1868. https://doi.org/10.1016/j.ecolecon.2010.05.002

Dong H, Li W, Eneji AE, Zhang D (2012). Nitrogen rate and plant density effects on yield and late-season leaf senescence of cotton raised on a saline field. Field Crops Research 126:137-144. https://doi.org/10.1016/j.fcr.2011.10.005

Dutt S, Sharma SD, Kumar P (2013a). Inoculation of apricot seedlings with indigenous arbuscular mycorrhizal fungi in optimum phosphorus fertilization for quality growth attributes. Journal of Plant Nutrition 36:15-31. https://doi.org/10.1080/01904167.2012.732648

Dutt S, Sharma SD, Kumar P (2013b). Arbuscular mycorrhizas and Zn fertilization modify growth and physiological behavior of apricot (Prunus armeniaca L.). Scientia Horticulturae 155:97-104. https://doi.org/10.1016/j.scienta.2013.03.012

Eady RR (2003). Current status of structure function relationships of vanadium nitrogenase. Coordination Chemistry Reviews 237:23-30. https://doi.org/10.1016/s0010-8545(02)00248-5

Egamberdieva D, Kucharova Z (2008). Cropping effects on microbial population and nitrogenase activity in saline arid soil. Turkish Journal of Biology 32:85-90.

Evans JR (1983). Nitrogen and photosynthesis in the flag leaf of wheat. Plant Physiology 72:297-302.

Enagbonma BJ, Babalola OO (2019). Environmental sustainability: a review of termite mound soil material and its bacteria. Sustainability 11:3847. https://doi.org/10.3390/su11143847

Fall S, Brauman A, Chotte J-L (2001). Comparative distribution of organic matter in particle and aggregate size fractions in the mounds of termites with different feeding habits in Senegal: Cubitermesniokoloensis and Macrotermes bellicosus. Applied Soil Ecology 17:131-140. https://doi.org/10.1007/s13213-019-1439-2

Fekete FA, Lanzi RA, Beaulieu JB, Longcope DC, Sulya AW, Hayes RN, Mabbott GA (1989). Isolation and preliminary characterization of hydroxamic acids formed by nitrogen-fixing Azotobacter chroococcum B-8. Applied and Environmental Microbiology 55(2):298-305. https://doi.org/10.1128/aem.55.2.298-305.1989 
Feng M, Adams JM, Fan K, Shi Y, Sun R, Wang D, ... Chu H (2018). Long-term fertilization influences community assembly processes of soil diazotrophs. Soil Biology and Biochemistry 126:151-158. https://doi.org/10.1016/j;soilbio.2018.08.021

Fischer D, Pfitzner B, Schmid M, Simoes-Araujo JL, Reis VM, Pereira W, ... Hartmann A (2012). Molecular characterization of the diazotrophic bacterial community unioculated and inoculated field-grown sugarecane (Saccharum sp.). Plant Soil 356:83-99. https://doi.org/10.1007/s11104-011-0812-0

Foster R, Subramaniam A, Mahaffey C, Carpenter E, Capone D, Zehr J (2007). Influence of the Amazon River plume on distribution of free-living and symbiotic cyanobacteria in the western tropical North Atlantic Ocean. Limnol. Oceanogr 52(2):517-532. https://doi.org/10.1007/s11104-011-1023-4

Fowler D, Coyle M, Skiba U, Sutton MA, Cape JN, Reis LJ, ... Voss M (2013). The global nitrogen cycle in the twentyfirst century. Philosophical Transactions of the Royal Society B: Biological Sciences 368(1621):20130164. https://doi.org/10.1098/rstb.2013.0164

French JRJ, Turner GL, Bradbury JF (1976). Nitrogen fixation by bacteria from the hindgut of termites. Journal of General Microbiology 95:202-206.

Frohlich J, Koustiane C, Kampfer P, Rossello-Mora R, Valens M, Berchtold M, ... Konig H (2007). Occurrence of rhizobia in the gut of the higher termite Nasutitermesnigriceps. Systematic and Applied Microbiology 30:68-74. https://doi.org/10.1016/j.syapm.2006.03.001

Fuentes-Ramirez LE, Jimenez-Salgado T, Abarca-Ocampo IR, Caballero-Mellado J (1993). Acetobacter diazotrophicus, an indoleacetic acid producing bacterium isolated from sugarcane cultivars of Mexico. Plant and Soil 154(2):145150. https://doi.org/10.1007/bfo0o12519

Fuhita Y, Takahashi Y, Chuganji M, Matsubara H (1992). The nifH-like (frx $C$ ) gene is involved in the biosynthesis of chlorophyll in the filamentous cyanobacterium Plectonemaboryanum. Plant and Cell Physiology 33:81-92. https://doi.org/10.1093/oxfordjournals.pcp.a078224

Gaby JC, Buckley DH (2014). A comprehensive aligned nifH gene database: a multipurpose tool for studies of nitrogenfixing bacteria. Database. https://doi.org/10.1093/database/bau001

Garba M, Cornelis WM, Steppe K (2011). Effect of termite mound material on the physical properties of sandy soil and on the growth characteristics of tomato (Solanum lycopersicumL.) in semi-arid Niger. Plant and Soil 338:451466. https://doi.org/10.1007/s11104-010-0558-0

Garcias-Bonet N, Arrieta JM, Duarte CM, Marba N (2016). Nitrogen-fixing bacteria in Mediterranean seagrass (Posidonia oceanica) roots. Auqtic Botany 131:57-60. https://doi.org/10.1016/j.aquabot.2016.03.002

Garg SK, Bhatnagar A, Kalla A, Narula N (2001). In vitro nitrogen fixation, phosphate solubilization, survival and nutrient release by Azotobacter strains in an aquatic system. Bioresource Technology 80:101-109. https://doi.org/10.3354/meps07714

Garg N, Pandey R (2016). High effectiveness of exotic arbuscular mycorrhizal fungi is reflected in improved rhizobial symbiosis and trehalose turnover in Cajanus cajan genotypes grown under salinity stress. Fungal Ecology 21:5767. https://doi.org/10.1016/j.funeco-2016.04.001

Gauri SS, Mandal SM, Dey S, Pati BR (2012). Biotransformation of p-coumaric acid and 2,4-dichlorophenoxy acetic acid by Azotobacter sp. strain SSB81. Bioresource Technology 126:350-353. https://doi.org/10.1016.j.biortech.2012.09.097

Gholami S, Shahsavani S, Nezarat S (2009). The effect of plant growth promoting rhizobacteria (PGRP) on germination, seedling growth and yield of maize. International Journal of Biological Life Sciences 1(1):35-40. https://doi.org/10.15258/sst.2015.43.3.04

Gillis M, Kersters K, Hoste B, Janssens D, Kroppenstedt RM, Stephan MP, ... De Ley J (1989). Acetobacter diazotrophicus, a nitrogen-fixing acid bacterium associated with sugarcane. International Journal of Systematic Bacteriology 48:327.

Gohre V, Paszkowski U(2006). Contribution of the arbuscular mycorrhizal symbiosis to heavy metal phytoremediation. Planta 223:1115-1122. https://doi.org/10.1007/s00425-006-0225-0

Goicoechea N, Merino S, Sanchez-Diaz M (2005). Arbuscular mycorrhizal fungi can contribute to maintain antioxidant and carbon metabolism in nodules of Anthyllis cytisoides L. subjected to drought. Journal of Plant Physiology 162:27-35. https://doi.org/10.1016/j.jplph.2004.03.011

Gomathi V, Ramalakshmi A, Ramasamy K (2018). Microbial diversity and fungal symbiont of termite ecosystem. International Journal of Current Microbiology and Applied Sciences 7(12):3283-3295. https://doi.org/10.20546/ijcmas.2018.712.380 
Gomez F, Furuya K, Takeda S (2005). Distribution of the cyanobacterium Richeliaintra cellularis as an epiphyte of the diatom Chaetoceroscompressus in the western Pacific Ocean. Journal of Plankton Research 27:323-330. https://doi.org/10.1093/[;ankt/fbio07

Gonzales-Lopez J, Martinez Toledo MV, Reina S, Salmeron V (1991). Root exudates of maize on production of auxins, gibberellins, cytokinins, amino acids and vitamins by Azotobacter chroococcum chemically defined media and dialyzed soil media. Toxicology and Environmental Chemistry 33:69-78.

Goss MJ, de Varennes A (2012). Soil disturbance reuces the efficacy of mycorrhizal associations for early soybean growth and $\mathrm{N}_{2}$ fixation. Soil Biology and Biochemistry 34:1167-1173. https://doi.org/10.1016/s0038-0717(02)00053-6

Guether M, Neuhaeuser B, Balestrini R, Dynowski M, Ludeqig U, Bonfante P (2009). A mycorrhizal-specific ammonium transporter from Lotus japnicus acquires nitrogen released by asrbuscular mycorrhizal fungi. Plant Physiology 150:73-83. https://doi.org/10.1104/pp.109.136390

Guisande-Collazo A, Gonzalez K, Souza-Alonso P (2016). Impact of an invasive nitrogen-fixing tree on arbuscular mycorrhizal fungi and the development of native species. AoB Plants 8:plw018. https://doi.org/10.1093/aobpla/plw018

Gutierrez-Zamora ML, Martinez-Romero E (2001). Natural endophytic association between Rhizobium etli and maize (Zea mays L.). Journal of Biotechnology 91:117-126. https://doi.org/10.1002/9781119053095.12

Hageman RV, Burris RH (1978). Dinitrogenase and nitrogenase reductase associate and dissociate with each catalytic cycle. Proceeding of the National Academy of Science of the USA 75:2699-2702.

Hammad SAR, Ali OAM (2014). Physiological and biochemical studies on drought tolerance of wheat plants by application amino acids and yeast extract. Annals of Agricultural Sciences 59:133-145. https://doi.org/10.1016/j.aoas.2014.06.018

Hara S, Morlkawa T, Wasal S, Kasahara Y, Koshiba T, Yamazaki K, ... Minamisawa K (2019). Identification of nitrogenfixing Bradyrhizobium associated with roots of field-grown sorghum by metagenome and proteome analyses. Frontiers in Microbiology 10:407. https://doi.org/10.3389/fmicb.2019.00407

Hartmann LS, Barnum SR (2010). Inferring the evolutionary history of Mo-dependent nitrogen fixation from phylogenetic studies of nifK and nifDK. Journal of Molecular Evolution 71:7-85. https://doi.org/10.1007/s00239-010-9365-8

Hemminga MA, Duarte CM (2000). Seagrass ecology. Cambridge University Press, Cambridge.

Herridge DF, Peoples MB, Boddey RM (2008). Global inputs of biological nitrogen fixation in agricultural systems. Plant and Soil 311:1-18. https://doi.org/10.1007/s11104-008-9668-3

Higashi M, Abe T, Burns TP (1992). Carbon-nitrogen balance and termite ecology. Proceedings of the Royal Society B: Biological Sciences 249:303-308. https://doi.org/10.1098/rspb.1992.0119

Horan NJ, Jarman TR, Dawes EAJ (1981). Effect of carbon source and inorganic phosphate concentration on the production of alginic acid by a mutant of Azotobacter vinelandii and on the enzyme involved in its biosynthesis. Journal of General Microbiology 127:185-191.

Hrynkiewicz K, Patz S, Ruppel S (2019). Salicornia europaea L. as an underutilized saline-tolerant plant inhabited by endophytic diazotrophs. Journal of Advanced Research 19:49-56. https://doi.org/10.1016/j.jare.2019.05.002

$\mathrm{Hu}$ J, Lin X, Bentivenga SP, Hou X-Y, Ji B (2019). Intraradical and extratadical communities of AM fungi associated with alfalfa respond differently to long-term phosphorus fertilization. Flora 258:151424. https://doi.org/10.31274/farmprogressreports-180814-2517

Hugenholtz P (2002). Exploring prokaryotic diversity in the genomic era. Genome Biology 3(2):1-8. https://doi.org/10.1186/gb-2002-3-2-review0003

Ingraffia R, Amato G, Frenda AS, Giambalvo D (2019). Impacts of arbuscular mycorrhizal fungi on nutrient uptake, $\mathrm{N}_{2}$ fixation, $\mathrm{N}$ transfer, and growth in a wheat/faba bean intercropping system. PLOS ONE 14(3):e0213672. https://doi.org/10.1371/journal.pone.0213672

Inomura K, Bragg J, Follows MJ (2017). A quantitative analysis of the direct and indirect costs of nitrogen fixation: a model based on Azotobacter vinelandii. The ISME Journal 11:166-175. https://doi.org/10.1038/ismej.2016.97

James EK, Reis VM, Olivares FL, Baldani JI, Dobereiner J (1994). Infection of sugar cane by the nitrogen-fixing bacterium Acetobacter diazotrophicus. Journal of Experimental Botany 45:757-766. https://doi.org/10.21203/rs.3.rs$103042 / v 1$

James EK (2000). Nitrogen fixation in endophytic and associative symbiosis. Field Crops Research 65:197-209. 
James EK, Gyaneshwar P, Barraquio WL, Mathan N, Ladha JK (2000). Endophytic diazotrophs associated with rice. In: Ladha JK, Reddy PM (Eds). The Quest for Nitrogen Fixation in Rice. International Rice Research Institute, Los Banos, pp 119-140.

James EK (2017). Nitrogen fixation. In: Encyclopedia of Applied Plant Sciences. Edition 2, Chapter 124, Academic Press. https://doi.org/10.1016/B978-0-12-394807-6.00124-6

Jarman TR (1979). Bacterial alginate synthesis. In: Barkeley US (Ed). Microbial Polysaccharides and Polysaccharases. Academic Press, London, United Kingdom, pp 35-50.

Jebara S, Drevon JJ, Jebara M (2010). Modulation of symbiotic efficiency and nodular antioxidant enzyme activites in two Phaseolus vulgaris genotypes under salinity. Acta Physiologiae Plantarum 32:925-932. https://doi.org/10.1007/s11738-010-0480-3

Ji R, Kappler A, Brune A (2000). Transformation and mineralization of synthetic ${ }^{14} \mathrm{C}$-labeled humic model compounds by soil-feeding termites. Soil Biology and Biochemistry 32:1281-1291. https://doi.org/10.1016/s0038 0717(00)00046-8

Ji R, Brune A (2001). Transformation and mineralization ${ }^{14} \mathrm{C}$-labeled cellulose, peptidoglycan, and protein by the soilfeeding termite Cubitermes orthoganthus. Biology and Fertility of Soils 33:166-174. https://doi.org/10.1099/ijs.0.64969-0

Jimenez DJ, Montana JS, Martinez MM (2011). Characterization of free nitrogen fixing of the genus Azotobacter in organic vegetable-grown Colombian soils. Brazilian Journal of Microbiology 42:846-858. https://doi.org/10.1590/s1517-83822011000300003

Jnawali AD, Ojha RB, Marahatta S (2015). Role of Azotobacter in soil fertility and sustainability- a review. Advances in Plants \& Agriculture Research 2(6):250-253.

Joerger RD, Bishop PE (1988). Bacterial alternative nitrogen fixation systems. Critical Reviews in Microbiology 16:1-14. https://doi.org/10.3109/10408418809104465

Johnson NC (2010). Ressources stoichiometry elucidates the structure and function of arbuscular mycorrhizas across scales. New Phytologist 185:631-647. https://doi.org/10.1111/j.1469-8137.2009.03110.x

Kafkas S, Ortas I (2009). Various mycorrhizal fungi enhance dry weights, P and Zn uptake of four Pistacia species. Journal of Plant Nutrition 32:146-159. https://doi.org/10.1080/01904160802609005

Kargi F, Ozmihci S (2002). Performance of azotobacter supplemented activated sludge in biological treatment of nitrogen deficient wastewater. Process Biochemistry 38:57-64. https://doi.org/10.1016/s0032-9592(02)00055-9

Ke X, Feng S, Wang J, Lu W, Zhang W, Chen M, Lin M (2019). Effect of inoculation with nitrogen-fixing bacterium Pseudomonasstutzeri A1501 on maize plant growth and the microbiome indigenous to the rhizosphere. Systematic and Applied Microbiology 42:248-260. https://doi.org/10.1016/j.syapm.2018.10.010

Kennedy IR, Tchan Y (1992). Biological nitrogen fixation in non-leguminous field crops: recent advances. Plant and Soil 141:93-118. https://doi.org/10.3724/sp.j.1011.2010.00089

Kennedy IR, Choudhury ATMA, Kecskes ML (2004). Non-symbiotic bacterial diazotrophs in crop-farming systems: can their potential for plant growth promotion be better exploited? Soil Biology and Biochemistry 36:1229-1244. https://doi.org/10.1186/1471-2180-10-36

Keshri J, Mishra A, Jha B (2013). Microbial population index and community structure in saline-alakine soil using gene targeted metagenomics. Microbiological Research 168:165-173. https://doi.org/10.1099/mic.0.29171-0

Khudhur AM, Askar KA (2013). Effect of some pesticides on growth, nitrogen fixation and nifgenes in Azotobacter chroococcum and Azotobacter vinelandii isolated from soil. Journal of Toxicology and Environmental Health Sciences 5(9):166-171. https://doi.org/10.5897/jtehs12.029

Kiers ET, Duhamel M, Beesetty Y, Mensah JA, Franken O, Verbruggen R, ... Bucking H (2011). Reciprocal rewards stabilize cooperation in the Mycorrhizal symbiosis. Science 333:880-882. https://doi.org/10.1126/science.1208473

Kirchhof G, Reis VM, Baldani JI, Eckert B, Dobereiner J, Hartmann A (1997). Occurrence, physiology and molecular analysis of endophytic diazotrophic bacteria in gramineous energy plants. Plant Soil 194:45-55. https://doi.org/10.3410/f.13336057.14702194

Kisa M, Duponnois R, Assikbetse K, Ramanankierana H, Thioulouse J, Lepage M (2006). Litter-forager termite mounds enhance the ectomycorrhizal symbiosis between Acacia holosticea A. Cunn. Ex G. Don and Scleroderma dictyosporum isolates. FEMS Microbiology Ecology 56:292-303. https://doi.org/10.1111/j.15746941.2006.00089.x 
Kizilkaya R (2008). Yield response and nitrogen concentrations of spring wheat (Triticum aestivum) inoculated with Azotobacter chroococcum. Ecological Engineering 33:150-156. https://doi.org/10.1016/j.ecoleng.2008.02.011

Kizilkaya R (2009). Nitrogen fixation capacity of Azotobacter spp. strains isolated from soils in different ecosystems and relationship between them and the microbiological properties of soils. Journal of Environmental Biology 30(1):7382. https://doi.org/10.1007/bf00709658

Kneip C, Lockhart P, Vo B, Maier UG (2007). Nitrogen fixation in eukaryotes- new models for symbiosis. BMC Evolutionary Biology 7:55. https://doi.org/10.1186/1471-2148-7-55

Knot JL, Kim SH, Ettl GJ, Doty SJ (2013). Biological nitrogen fixation and biomass accumulation within poplar clones as a result of inoculations with diazotrophic endophyte consortia. New Phytologist. https://doi.org/10.1111/nph.12536

Koch AL (2003). Were Gram-positive rods the first bacteria? Trends in Microbiology11:166-170. https://doi.org/10.1016/s0966-842x(03)00063-5

Koskey G, Mburu SW, Njeru EM, Kimiti JM, Ombori O, Maingi JM (2017). Potential of native rhizobia in enhancing nitrogen fixation and yields of climbing beans (Phaseolus vulgaris L.) in contrasting environments of Eastern Kenya. Frontiers in Plant Science 8:443. https://doi.org/10.3389/fpls.2017.00443

Kuhnigk T, Branke J, Krekeler D, Cypionka H, Konig H (1996). A feasible role of sulfate-reducing bacteria in the termite gut. Systematic and Applied Microbiology 19:139-149. https://doi.org/10.1016/s0723-2020(96)80039-7

Kumar P, Joolka NK, Sharma SD (2006). Indigenous arbuscular mycorrhiza in apple orchards of north-western Himalayan region. Haryana Journal of Horticultural Sciences 35:207-210.

Kumar P, Sharma SD (2009). Correlation of AM spore number, percent root colonization and Azotobacter count with plant growth, fruit yield and leaf nutrient content of Royal Delicious apple. Environment and Ecology 27(4B):2107-2111. https://doi.org/10.1016/b978-0-444-63987-5.00021-9

Kumar U, Panneerselvam P, Govindasamy V, Vithalkumar L, Senthilkumar M, Banik A, Annapurna K (2017). Longterm aromatic rice cultivation effect on frequency and diversity of diazotrophs in its rhizosphere. Ecological Engineering 101:227-236. https://doi.org/10.1016/j.ecoleng.2017.02.010

Kumar P, Tilak M, Sivakumar K, Saranya K (2018). Studies on the assessment of major nutrients and microbial population of termite mound soil. International Journal of Forestry and Crop Improvement 9:13-17. https://doi.org/10.15740/has/ijfci/9.1/13-17

Kwak Y, Shin JH (2016). First Azospirillum genome from aquatic environments: whole-genome sequence of Azospirilumthiophilum BV-S , a novel diazotroph harboring a capacity of sulfur-chemolithotrophy from a sulfide spring. Marine Genomics 25:21-24. https://doi.org/10.1016/j.margen.2015.11.001

La Rue TA (1977). The bacteria. In: Hardy RWF, Silver WS (Eds). A Treaties on Dinitrogen Fixation. Section III, Biology. Wiley-Interscience Pub., London, Sydney, Toronto pp 19-63.

LaRoche J, Breitbarth E (2005). Importance of the diazotrophs as a source of new nitrogen in the ocean. Journal of Sea Research 53:67-91. https://doi.org/10.1007/s11-56-007-9066-3

Lee KS, Park SR, Kim YK (2007). Effects of irradiance, temperature, and nutrients on growth dynamics of seagrasses: a review. Journal of Experimental Marine Biology and Ecology 350:144-175. https://doi.org/10.1016/j.jembe.2007.06.016

Leigh JA (2000). Nitrogen fixation in methanogens: the archaeal perspective. Current Issues in Molecular Biology 2(4):125-131. https://doi.org/10.1016/j.jembe.2007.06.013

Lévai L, Veres S, Bákonyi N, Gajdos É (2008). Can wood ash and biofertilizer play a role in organic agriculture? AgronomskiGlasnic 3:263-271.

Levy Y, Dodd J, Krikun J (1983). Effect of irrigation, water salinity and rootstock on the vertical distribution of vesiculararbuscular mycorrhiza in citrus roots. New Phytologist 95:397-403.

Levy-Booth DJ, Prescott CE, Grayston SJ (2014). Microbial functional genes involved in nitrogen fixation, nitrification and denitrification in forest ecosystems. Soil Biology and Biochemistry 75:11-25. https://doi.org/10.1016.j.soilbio.2014.03.021

Li M, Li H, Wang K, Shi L, Liu J, Zhang L (2016). Effect of arbuscular mycorrhizae on the growth, photosynthetic characteristics and cadmium uptake of peanut plant under cadmium stress. Envrionmental Chemistry 35:23442352.

Lilburn TG, Kim KS, Ostrom KR, Byzek JR, Leadbetter JA, Breznak JA (2001). Nitrogen fixation by symbiotic and freeliving spirochetes. Science 292:2495-2498. https://doi.org/10.1126/science.1060281 
Lin Y, Ye G, Liu D, Ledgard S, Luo J, Fan J, ... Ding W (2018). Long-term application of lime or pig manure rather than plant residues suppressed diazotroph abundance and diversity and altered community structure in an acidic ultisol. Soil Biology and Biochemistry123:218-228. https://doi.org/10.1016/j.soilbio.2018.05.018

Liu H-L, Zhou H-N, Xing W-M, Zhao J-F, Li S-X, Huang J-F, Bi R-C (2004). 2.6 A resolution crystal structure of the bacterioferritin from Azotobacter vinelandii. FEBS Letters 573:93-98. https://doi.org/10.1016/j.febslet.2004.07.054

Liu N, Shao C, Sun H, Liu Z, Guan Y, Wu L, ... Zhang B (2020) Arbuscular mycorrhizal fungi biofertilizer improves American ginseng (Panax quinquefolius L.) growth under the continuous cropping regime. Geoderma 363:114155. https://doi.org/10.1016/j.geoderma.2019.114155

Long X, Chen C, Xu Z, Oren R, He J-Z (2012). Abundance and community structure of ammonia-oxidizing bacteria and archae in a temperate forest ecosystem under ten-years elevated $\mathrm{CO}_{2}$. Soil Biology and Biochemistry 46:163-171. https://doi.org/10.20944/preprints202008.0300.v2

Luo Y, Wasserfallen A (2001). Gene transfer systems and their applications in Archaea. Systematic and Applied Microbiology 24:15-15. https://doi.org/10.21203/rs.3.rs-175664/v1

Mahato S, Kafle A (2018). Comparative study of Azotobacter with or without other fertilizers on growth and yield of wheat in Western hills of Nepal. Annals of Agarian Science 16:250-256. https://doi.org/10.1016/j.aasci.2018.04.004

Majeed MZ, Miambi E, Robert A, Bernoux M, Brauman A (2012). Xylophagous termites: a potential sink for atmospheric nitrous oxide. European Journal of Soil Biology 53:121-125. https://doi.org/10.1016/j.ejsobi.2012.10.002

Makarova KS, Aravind L, Wolf YI, Tatusov RL, Minton KW, Koonin EV, Daly MJ (2001). Genome of the extremely radiation-resistant bacterium Deinococcusradiodurans viewed from the perspective of comparative genomics. Microbiol. Molecular Biology Reviews 65:44-79. https://doi.org/10.1128/mmbr.65.1.44-79.2001

Mancinelli RL, McKay CP (1998). Evolution of nitrogen cycling. Origins of Life 18:311-325. https://doi.org/10.1007/bf01808213

Manchanda G, Garg N (2007). Endomycorrhizal and rhizobial symbiosis: How much do they share? Journal of Plant Interactions 2(2):79-88. https://doi.org/10.1080/17429140701558000

Marques ACR, Oliveira LBD, Nicoloso FT, Jacques RJS, Giacomini SJ, Quadros FLFD (2017). Biological nitrogen fixation in $\mathrm{C}_{4}$ grasses of different growth strategies of South America natural grasslands. Applied Soil Ecology 113:54-62. https://doi.org/10.1016/j.apsoil.2017.01.011

Martinez Toledo MV, Moreno J, De laRubia T, Gonzalez-Lopez J (1989). Root exudates of Zea mays and production of auxins, gibberellins and cytokinins by Azotobacter chroococcum. Plant and Soil 110:149-152. https://doi.org/10.1007/bf02143553

Martyniuk S, Martyniuk M (2003). Occurrence of AzotobacterSpp. in some polish soils. Polish Journal of environmental Studies 12(3):371-374. https://doi.org/10.1007/978-3-662-06083-4-15

Massa N, Cesaro P, Todeschini V, Capraro J, Scarafoni A, Cantamessa S, ... Bona E (2020). Selected autochthonous rhizobia, applied in combination with AM fungi, improve seed quality of common bean cultivated in reduced fertilization condition. Applied Soil Ecology 148:103507. https://doi.org/10.1016/j.apsoil.2020.103507

Mao Y, Yannarell AC, Mackie R (2011). Changes in N-transforming archaea and bacteria in soil during the establishment of bioenergy crops. PLOS One 6(9):e24750. https://doi.org/10.371/journal.pone.0024750

Martinez-Toledo MV, Gonzalez-Lopez J, de la Rubia T, Ramos-Cormenzana A (1985). Isolation and characterization of Azotobacter chroococcum from the roots of Zea mays. FEMS Microbiology Ecology 31:197-203. https://doi.org/10.1111/j.1574-6968.1985.tb01149.x

Matthews SS, Sparkes DL, Bullard MJ (2001). The response of wheat to inoculation with the diazotroph Azorhizobiumcaulinodans. Aspects of Applied Biology 63:35-42.

Mbarki S, Cerda A, Brestic M, Mahendra R, Abdelly C, Pascual JA (2017). Vineyard compost supplemented with Trichoderma Harzianum T78 improve saline soil quality. Land Degradation and Development 28:1028-1037. https://doi.org/10.1002/ldr.2554

McRose DL, Lee A, Kopf SH, Baars O, Kraepeil AML, Sigman DM, ... Zhang X (2019). Effect of iron limitation on the isotopic composition of cellular and released fixed nitrogen in Azotobactervinelandii. Geochimica et Cosmochimica Acta 244:12-23. https://doi.org/10.1016/j.gca.2018.09.23

Mertins JW (1973). Nitrogen fixation in termites. Nature 244(5418):577-580. 
Miller RW, Rady RR (1988). Molybdenum and vanadium nitrogenases of Azotobacter chroococcum. Low temperature favours N2 reduction by vanadium nitrogenase. Biochemical Journal 256:429-432. https://doi.org/10.1042/bj2560429

Mittal A, Yadav A, Singh G, Anand RC, Aggarwal NK (2011). Comparative nitrogen fixation by mesophilic (HTS) visà-vis thermotolerant mutants (HTR) of Azotobacterchroococcum at high temperature and their effect on cotton biomass. Jundishapur Journal of Microbiology 4(2):105-114.

Miyagawa S, Koyama Y, Kokubo M, Matsushita Y, Adachi Y, Sivilay S, ... Oba S (2011). Indigenous utilization of termite mounds and their sustainability in a rice growing village of the Central Plain of Laos. Journal of Ethnobiology and Ethnomedicine 7:24. https://doi.org/10.1186/1746-4269-7-24

Moisander PH, Cheshire LA, Braddy J, Calandrino ES, Hoffman M, ... Paerl HW (2012). Facultative diazotrophy increases Cylindrospermopsisraciborskii competitiveness under fluctuating nitrogen availability. FEMS Microbiology Ecology 79:800-811. https://doi.org10.1111/j.1574-6941.2011.01264.X

Momose A, Hiyama T, Nishimura K, Ishizaki N, Ishikawa S, Yamamoto M, ... Ohyama T (2013). Characteristics of nitrogen fixation and nitrogen release from diazotrophic endophytes isolated from sugarcane stems. Bull Fac Agric Niigata Univ 66(1):1-9. https://doi.org/10.1023/a:1016529015349

Montanez A, Abreu C, Gill PR, Hardarson G, Sicardi M (2008). Biological nitrogen fixation in maize (Zea mays L.) by $15 \mathrm{~N}$ isotope-dilution and identification of associated culturable diazotrophs. Biology and Fertility of Soils 45:253263. https://doi.org/10.1007/s00374-008-0322-2

Mrkovacki N, Milic V (2001). Use of Azotobacter chroococcum as potentially useful in agricultural application. Annals of Microiology 51:145-159. https://doi.org/10.2298/zmspn0201023m

Muangthong A, Youpensuk S, Rerkasem B (2015). Isolation and characterization of endophytic nitrogen fixing bacteria in sugarecane. Tropical Life Sciences Research 26(1):41-51.

Mus F, Crook MB, Garcia K, Costas AG, Geddes BA, Kouri ED, ... Peters JW (2016). Symbiotic nitrogen fixation and the challenges to its extension to nonlegumes. Applied and Environmental Microbiology 82(13):3698-3710. https://doi.org/10.1128/aem.01055-16

Mwangi SN, Karanja NK, Boga H, Kahindi JHP, Muigai A, Odee D, Mwenda GM (2011). Genetic diversity and symbiotic efficiency of legume nodulating bacteria from different land use systems in Taita Taveta, Kenya. Tropical and Subtroical Agroecosystems13:109-118.

Nafady NA, Hassan EA, Abd-Alla MH, Bagy MMK (2018). Effectiveness of eco-friendly arbuscular mycorrhizal fungi biofertilizer and bacterial feather hydrolysate in promoting growth of Vicia faba in sandy soil. Biocatalysisand Agricultural Biotechnology 16:140-147. https://doi.org/10.1016/j.bcab.2018.07.024

Nag NK, Dash B, Gupta SB, Khokher D, Soni R (2018). Evaluation of stress tolerance of Azotobacter isolates. Biologija 64(1):82-93. https://doi.org/10.6001/biologija.v64i1.3662

Nardi JB, Mackie RI, Dawson JO (2002). Could microbial symbionts of arthropod guts contribute significantly to nitrogen fixation in terrestrial ecosystem? Journal of Insect Physiology 48:751-763. https://doi.org/10.1016/s0022-1910(02)00105-1

Navarro-Gonzalez R, McKay CP, Mvondo DN (2001). A possible nitrogen crisis for Archaean life due to reduced nitrogen fixation by lightning. Nature 412:61-64. https://doi.org/10.1038/35083537

Ngugi DK, Brune A (2011). Nitrate reduction, nitrous oxide formation, and anaerobic ammonia oxidation to nitrite in the gut of soil-feeding termites (Cubitermes and Ophiotermes spp.). Environmental Microbiology 14:860-871. https://doi.org/10.1111/j.1462-2920.2011.02648.x

Nomata J, Mizoguchi T, Tamiaki H, Fujita Y (2006). A second nitrogenase-like enzyme for bacteriochlorophyll biosynthesis-reconstitution of chlorophyllide a reductase with purified $\mathrm{x}$-protein (bchX) and yz-protein (bchYbchZ) from Rhodobacter capsulatus. The Journal of Biological Chemistry 281:15021-15028. https://doi.org/10.1074/jbc.m601750200

Odelade KA, Barbalola OO (2019). Bacteria, fungi and archaea domains in rhizospheric soil and their effects in enhancing agricultural productivity. International Journal of Environmental Research and Public Health 16:3873. https://doi.org/10.3390/ijerph16203873

Offre P, Spang A, Schleper C (2013). Archaea in biogeochemical cycles. Annual Review of Microbiology 67:437-457. https://doi.org/10.1146/annurev-micro-092412-155614

Ohkuma M, Noda S, Usami R, Horikoshi K, Kudo T(1996). Diversity of nitrogen fixation genes in the symbiotic intestinal microflora of the termite Reticulitermes speratus. Applied and Environmental Microbiology 62(8):2747-2752. https://doi.org/10.1016/j.tim.2014.07.007 
Olson RA, Kurtz LT (1982). Crop nitrogen requirements, utilization and fertilization. In: Stephenson FJ (Ed). Nitrogen in Agricultural Soils. American Society of Agronomy, Madison, WI, pp 567-604.

Orr CH, James A, Leifert C, Cooper JM, Cummings SP (2011). Diversity and activity of free-living nitrogen-fixing bacteria and total bacteria in organic and conventionally managed soil. Applied and Environmental Microbiology 77:911-919. https://doi.org/10.1128/aem.01250-10

Ortiz-Marquez JCF, Nascimento MD, Curatti L (2014). Metabolic engineering of ammonium release for nitrogen-fixing multispecies microbial cell-factories. Metabolic Engineering 23:154-164. https://doi.org/10.1016/j.ymben.2014.03.022

Papineau D, Mojzsis SJ, Karhu JA, Marty B (2005). Nitrogen isotopic composition of ammoniated phyllosilicates: case studies from Precambrian metamorphosed sedimentary rocks. Chemical Geology 216(1-2):37-58. https://doi.org/10.1016/j.chemgeo.2004.10.009

Patra AK, Abbadie L, Clays-Josserand A, Degrange V, Grayston SJ, Guillaumaud N, ... Le Roux X (2006). Effects of management regime and plant species on the enzyme activity and genetic structure of $\mathrm{N}$-fixing, denitrifying and nitrifying bacterials communities in grassland soils. Environmental Microbiology 8:1005-1016. https://doi.org/10.1111/j.1462-2920.2006.00992.x

Pereira MES, Schloter-Hai B, Schloter M, Salles J (2013). Temporal dynamics of abundance and composition of nitrogenfixing communities across agricultural soils. PLoS One8:e74500. https://doi.org/10.1371/journal.pone.0074500

Philippot K, Hallin S, Schloter M (2007). Ecology of denitrifying bacteria in agricultural soil. Advances in Agronomy 96:249-305. https://doi.org/10.1371/journal.pone.0074500

Post E, Kleiner D, Oelze J (1983). Whole cell respiration nitrogenase activities in Azotobacter vinelandii growing in oxygen controlled continuous culture. Archives of Microbiology 134:68-72.

Prayitno J, Rolfe B (2010). Characterization of endophytic diazotroph bacteria isolated from rice. HAYATI Journal of Biosciences 17(2):73-78. https://doi.org/10.4308/hjb.17.4.173

Puschel D, Janouskova M, Voriskova A, Gryndlerova H, Vosatka M, Jansa J (2017). Arbuscular mycorrhiza stimulates biological nitrogen fixation in two Medicago spp. through improved phosphorus acquisition. Frontiers in Plant Science 8:390. https://doi.org/10.1007/s00573-018-00878-8

Rago L, Zecchin S, Villa F, Goglio A, Corsini A, Cavalca L, Schievano A (2019). Bioelectrochemical nitrogen fixation (e$\mathrm{BNF}$ ): electro-stimulation of enriched biofilm communities drives autotrophic nitrogen and carbon fixation. Bioelectrochemistry 125:105-115. https://doi.org/10.1016/j.bioelechem.2018.10.002

Rahav E, Giannetto MJ, Bar-Zeev E (2016). Contribution of mono and polysaccharides to heterotrophic $\mathrm{N}_{2}$ fixation at the eastern Mediterranean coastline. Scientific Report 6:27858. https://doi.org/10.1038/srep27858

Raimam MP, Albino U, Cruz MF, Lovato GM, Spago F, Ferracin TP, ... Andrade G (2007). Interaction among free-living $\mathrm{N}$-fixing bacteria isolated from Droseravillosa var. villosa and AM fungi (Glomus clarum) in rice (Oryza sativa). Applied Soil Ecology 35:25-34. https://doi.org/10.1016/j.apsoil.2006.05.013

Ratten J-M, LaRoche J, Desai DK, Shelley RU, Landing WM, Boyle E, ... Langlois R (2015). Sources of iron and phosphate affect the distribution of diazotrophs in the North Atlantic. Deep-Sea Research II 116:332-341. https://doi.org/10.1016/j.dsr2.2014.11.012

Ravikumar S, Kathiresan K, Ignatiammal STM, Selvam MB, Shanthy S (2004). Nitrogen-fixing azotobacters from mangrove habitat and their utility as marine biofertilizers. Journal of Experimental Marine Biology and Ecology 312:5-17. https://doi.org/10.1016/s0022-0981(04)00566-0

Raymod J, Siefert JL, Staples CR, Blankenship RE (2004). The natural history of nitrogen fixation. Molecular Biology and Evolution 21(3):541-554. https://doi.org/10.1093/molbev/msh047

Reardon CL, Gollany HT, Wuest SB (2014). Diazotroph community structure and abundance in wheat-fallow and wheat-pea crop rotations. Soil Biology and Biochemistry 69:406-412. https://doi.org/10.1016/j.soilbio.2013.10.038

Reed SC, Cleveland CC, Townsend AR (2011). Functional ecology of free-living nitrogen fixation: a contemporary perspective. Annual Review of Ecology, Evolution and Systematics 42:489-512. https://doi.org/10.1146/annurev-ecolsys-102710-145034

Rehder D (2000). Vanadium nitrogenase. Journal of Inorganic Biochemistry. 80:133-136. https://doi.org/10.1016/s0162-0134(00)00049-0

Reis VM, dos Reis FB, Quesada DM, de Oliveira OCA, Alves BJR, Urquiaga S, Boddey RM (2001). Biological nitrogen fixation associated with tropical pasture grasses. Australian Journal of Plant Physiology 28:837-844. https://doi.org/10.1071/pp01079 
Reysenbach AL, Ehringer M, Hershberger K (2000). Microbial diversity at $83^{\circ} \mathrm{C}$ in Calcite Springs, Yellowstone National Park: another environment where the Aquificales and Korarchaeota coexist. Extremophiles 4:61-67. https://doi.org/10.1007/s007920050008

Ribeiro CW, Alloing G, Mandon K, Frendo P (2015). Redox regulation of differentiation in symbiotic nitrogen fixation. Biochimica et Biophysica Acta 1850:1469-1478. https://doi.org/101016/j.bbagen.2014.11.018

Ritchie ME, Raina R (2016). Effects of herbivores on nitrogen fixation by grass endophytes, legume symbionts and freeliving soil surface bacteria in the Serengeti. Pedobiologia 59:233-241. https://doi.org/10.1016/j.pedobi.2016.09.001

Rodriqgues MA, Ladeira LC, Arrobas M (2018). Azotobacter-enriched organic manures to increase nitrogen fixation and crop productivity. European Journal of Agronomy 93:88-94. https://doi.org/10.1016/j.eja.2018.01.002

Romero-Perdomo F, Abril J, Camelo M, Moreno-Galvan A, Pastrana I, Rojas-Tapias D, Bonilla R (2017). Azotobacter chroococcum as a potentially useful bacterial biofertilizer for cotton (Gossypium hirsutum): effect in reducing N fertilization. Revista Argentina De Microbiologia 49(4):377-383. https://doi.org/10.1016/j.ram.2017.04.006

Rojas-Tapias D, Ortiz-Vera M, Rivera D, Kloepper J, Bonilla R (2013). Evaluation of three methods for preservation of Azotobacter chroococcum and Azotobacter vinelandii. Universitas Scientiarum 18(2):129-139. https://doi.org/10.11144/javeriana.sc18-2.etmp

Roper MM, Ladha JK (1995). Biological $\mathrm{N}_{2}$ fixation by heterotrophic and phototrophic bacteria in association with straw. Plant and Soil 174:211-224. https://doi.org/10.1007/978-94-011-0053-3-10

Rosch C, Mergel A, Bothe H (2002). Biodiversity of denitrifying and dinitrogen-fixing bacteria in an acid forest soil. Applied and Environmental Microbiology 68:3818-3829. https://doi.org/10.1128/aem.68.8.3818.2002

Rosenblueth M, Martinez-Romero E (2004). Rhizobiumetli maize populations and their competitiveness for root colonization. Archives of Microbiology 181:337-344. https://doi.org/10.1007/s00203-004-0661-9

Rosenblueth M, Ormeno-Orrillo E, Lopez-Lopez A, Rogel MA, Reyes-Hernandez BJ, Martinez-Romero JC, ... MartinezRomero E (2018). Nitrogen fixation in cereals. Frontiers in Microbiology 9:1794. https://doi.org/10.3389/fmicb.2018.01794

Rueda D, Valencia G, Soria N, Rueda BB, Manjunatha B, Kundapur RR, Selvanayagam M (2016). Effect of Azospirillum spp. and Azotobacter spp. on the growth yield of strawberry (Fragaria vesca) in hydroponic system under different nitrogen levels. Journal of Applied Pharmaceutical Science 6(01):048-054. https://doi.org/10.7324/japs.2016.600108

Ruiz-Rueda O, Hallin S, Baneras L (2009). Structure and function of denitrifying and nitrifying bacterial communities in relation to the plant species in a constructed wetland. FEMS Microbiology Ecology 67:308-319. https://doi.org/10.1111/j.1574-6941.2008.00615x

Ruiz-Lozano JM, Porcel R, Azcon C, Aroca R (2012). Regulation by arbuscular mycorrhizae of the integrated physiological response to salinity in plants: new challenges in physiological and molecular studies. Journal of Experimental Botany 63(11):4033-4044. https://doi.org/10.1093/jxb/ers 126

Sabra W, Zeng A-P, Lunsdorf H, Deckwer W-D (2000). Effect of oxygen on formation and structure of Azotobacter vinelandii alginate and its role in protecting nitrogenase. Applied and Environmental Microbiology 66(9):40374044. https://doi.org/10.1093/jxb/err266

Sadoff HL (1975). Encystment and germination in Azotobacter vineladii. Bacteriology Review 39:516-539.

Saia S, Amato G, Frenda AS, Giambalvo D, Ruisi P (2014). Influence of arbuscular mycorrhizae on biomass production and nitrogen fixation of berseem clover plants subjected to water stress. PLOS One 9(3):e90738. https://doi.org/10.1371/journal.pone.0090738

Salmeron V, Martinez Toledo MV, Gonzalez Lopez J (1990). Nitrogen fixation and production of auxins, gibberellins and cytokinin by Azotobacter chroococcum strain isolated from root of Zea mays in presence of insoluble phosphate. Chemosphere 20:417-422. https://doi.org/10.2134/agronj2012.0070

Santi C, Bogusz D, Franche C (2013). Biological nitrogen fixation in non-legume plants. Annals of Botany 111:743-767. https://doi.org/10.1093/aob/mct048

Sapountzis P, de Verges J, Rousk K, Cilliers M, Vorster BJ, Poulsen M (2016). Potential for nitrogen fixation in the fungusgrowing termite symbiosis. Frontiers in Microbiology 7:1993. https://doi.org/10.3389/fmicb.2016.01993

Sariv Z, Ragoviv B (1963). The influence of the maize on the dynamic of Azotobacter in the soil. Soil Plant 13:273-277.

Savenkova L, Gercberga Z, Kizhlo Z, Stegantseva E (1999). Effect of phosphate supply and aeration on poly- $\beta$ hydroxybutyrate production in Azotobacterchroococcum. Process Biochemistry 34:109-114. https://doi.org/10.1016/s0032-9592(98)00070-3 
Seesitsch A, Hardoim P, Doering J, Wilharter A, Krause A, Woyke T, ... Reinhold-Hurek B (2012). Functional characteristics of an endophyte community colonizing rice roots as revealed by metganeomic analysis. Molecular Plant Microbe Interactions 25:28-36. https://doi.org/10.1094/mpmi-08-11-0204

Sevilla M, Burris RH, Guanpala N, Kennedy C (2001). Comparison of benefit to sugarcane plant growth and ${ }^{15} \mathrm{~N}_{2}$ incorporation following inoculation of sterile plants with Acetobacter diazotrophicus wild-type and Nif-mutant strains. Molecular Plant-Microbe Interact 14(3):358-366. https://doi.org/10.1094/mpmi.2001.14.3.358

Sciotti MA, Chanfon A, Hennecke H, Fischer HM (2003). Disparate oxygen responsiveness of two regulatory cascades that control expression of symbiotic genes in Bradyrhizobium japonicum. Journal of Bacteriology 185:5639-5642. https://doi.org/10.1128/jb.185.18.5639-5642.2003

Seefeldt IC, Hoffman BM, Dean DR (2009). Mechanism of Mo-dependent nitrogenase. Annual Review of Biochemistry 78:701-722. https://doi.org/10.1146/annurev.biochem.78.070907.103812

Sellstedt A, Richau KH (2013). Aspects of nitrogen-fixing actinobacteria, in particular free-living and symbiotic Frankia. FEMS Microbiology Letters 342:179-186. https://doi.org/10.1111/1574-6968.12116

Shahrajabian MH, Soleymani A, Naranjani L (2011). Grain yield and forage characteristics of forage sorghum under different plant densities and nitrogen levels in second cropping after barley in Isfahan, Iran. Research on Crops 12(1):68-78. https://doi.org/10.9734/ijpss/201732460

Shahrajabian MH, Soleymani A (2017). Responses of physiological indices of forage sorghum under different plant populations in various nitrogen fertilizer treatments. International Journal of Plant and Soil Science 15(2):1-8. https://doi.org/10.9734/ijpss/2017/32460

Shahrajabian MH, Khoshkharam M, Sun W, Cheng Q (2019). Exploring responses of berseem clover cultivars in low input cultivation management for agricultural sustainability. World Scientific News 131:197-206.

Sharma SD, Kumar P (2008). Relationship of arbuscular mycorrhizal fungi and Azotobacter with plant growth, fruit yield, soil and leaf nutrient status of mango orchards in north-western Himalayan region of India. Journal of Applied Horticulture 10:172-176. https://doi.org.10.37855/jah.2008.v10i02.34

Sharma SD, Kumar P, Singh SK, Patel VB (2009). Indigenous AM fungi and Azotobacter chroococcum isolates, and their screening from citrus seedlings at different levels of inorganic fertilizers application. Indian Journal of Horticulture 64:183-189.

Sharma SD, Kumar P, Bhardwaj SK, Yadav SK (2011). Screening and selecting novel AM fungi and Azotobacter strain for inoculating apple under soil solarization and chemical disinfestations with mulch practices for sustainable nursery management. Scientia Horticulturae 130(1):164-174. https://doi.org/10.1016/j.scienta.2011.06.032

Sharma SD, Sharma NC, Sharma CL, Kumar P, Chandel A (2012). Glomus-Azotobacter symbiosis in apple under reduced inorganic nutrient fertilization for sustainable and economic orcharding enterprise. Scientia Horticulturae 146:175-181. https://doi.org/10.37855/jah.2001.v03i02.03

Sharma SD, Kumar P, Yadav SK (2014). Glomus-Azotobacter association affects phenology of mango seedlings under reduced soil nutrient supply. Scientia Horticulturae 173:86-91. https://doi.org/10.17221/2011-pse

Suzuki S, He Y, Oyaizu H (2002). Indole-3-acetic acid production in Pseudomonas fluorescence and its association with suppression of creeping bent grass brown patch. Current Microbiology 47(2):138-143. https://doi.org/10.1007/s00284-002-3968-2

Shiozaki T, Chen Y-LL, Lin Y-H, Taniuchi Y, Sheu D-S, Furuya K, Chen H-Y (2014). Seasonal variations of unicellular diaztroph groups A and B, and Trichodesmium in the northern South China Sea and neighboring upstream Kuroshio current. Continental Shelf Research 80:20-31. https://doi.org/10.1016/j.csr.2014.02.015

Shridhar BS (2012). Review: nitrogen fixing Microorganisms. International Journal ofMicrobiological Research 3(1):4652. https://doi.org/10.1016/j.cst.2021.014359

Singh R, Adholeya A (2004). Interaction between arbuscular mycorrhizal fungi and plant-growth promoting rhizobacteria. Mycorrhiza News 15:16-17.

Sivasakthi S, Saranraj P, Sivasakthivelan P (2017). Biological nitrogen fixation by Azotobacter sp.- A review. Indo-Asian Journal of Multidisciplinary Research 3(5):1274-1284.

Smith SE, Read DJ (1997). Growth and carbon economy of VA mycorrhizal plants. In: Mycorrhizal Symbiosis. Snd et. Academic, London, pp 105-125. https://doi.org/10.1016/b978-012652840-4/50005-X

Smith SE, Jakobsen I, Grnlund M, Smith FA (2011). Roles of arbuscular mycorrhizas in plant phosphorus nutrition: interactions between pathways of phosphorus uptake in arbuscular mycorrhizal roots have important implications for understanding and manipulating plant phosphorus acquisition. Plant Physiology 156:1050-1057. https://doi.org/10.1104/pp.111.174581 
Smith-Moore C, Grundern AM (2018). Bacteria and archaea as the sources of traits for enhanced plant phenotypes. Biotechnology Advances 36:1900-1916. https://doi.org/10.1016/j.biotechadv.2018.07.007

Soleymani A, Shahrajabian MH, Naranjani L (2011a). Changes in qualitative characteristics and yield of three cultivars of Berseem clover intercropped with forage corn in low input farming system. Journal of Food, Agriculture and Environment 9(1):345-347.

Soleymani A, Shahrajabian MH, Naranjani L (2011b). Study the effect of plant densities and nitrogen fertilizers on yield, yield components and grain protein of grain sorghum. Journal of Food, Agriculture and Environment 9(3\&4):244-246. https://doi.org/10.47176/jcpp.9.4.22255

Soleymani A, Shahrajabian MH (2012a). Forage yield and quality in intercropping of forage corn with different cultivars of berseem clover in different levels of nitrogen fertilizer. Journal of Food, Agriculture and Environment 10(1):602-604.

Soleymani A, Shahrajabian MH (2012b). Effects of different levels of nitrogen on yield and nitrate content of four spring onion genotypes. International Journal of Agriculture and Crop Sciences 4(4):179-182. https://doi.org/10.5539/ijb.v4n4p75

Soleymani A, Shahrajabian MH, Modaresi M (2012). Influence of irrigation intervals and different levels of nitrogen fertilizer on yield and prussic acid content in second cropping of forage sorghum grown after wheat. Research on Crops 13(2):498-502.

Souillard N, Magot M, Possot O, Sibold L (1988). Nucleotide sequence of regions homologous nifH (nitrogenase fe protein) from the nitrogen-fixing archaebacteria Methanococcusthermolithotrophicus and Methanobacteriumivanovii: evolutionary implications. Journal of Molecular Evolution 27:65-76. https://doi.org/10.1007/bf02099731

Spang A, Caceres EF, Ettema TJG (2017). Genomic exploration of the diversity, ecology and evolution of the archaeal domain of life. Science357. https://doi.org/10.1126/science.aaf3883

Sprent JI, Parsons R (2000). Nitrogen fixation in legume and non-legume trees. Field Crops Research 65:183-196. https://doi.org/10.3410/f.728374424.793558292

Staples CR, Lahiri S, Raymond J, Von Herbulis L, Mukhophadhyay B, Blankenship RE (2007). Exprssion and association of group IV nitrogenase nifD and nifH homologs in the non-nitrogen-fixing archaeon Methanocaldococcus jannaschii. Journal of Bacteriology 189:7392-7398. https://doi.org/10.1128/jb.00876-07

Sullivan JT, Trzebiatowski JR, Cruickshank RW, Gouzy J, Brown SD, Elliot RM, ... Ronson CW (2002). Comparative sequence analysis of the symbiosis island of Mesorhizobium loti strain R7A. Journal of Bacteriology. 184:30863095. https://doi.org/10.1128/jb.184.11.3086-3095.2002

Sun W, Shahrajabian MH, Cheng Q (2019). Anise (Pimpinella anisum I.), a dominant spice and traditional medicinal herb for both food and medicinal purposes. Cogent Biology 5(1673688):1-25. https://doi.org/10.1080/233112025.2019.1673688

Suyal DC, Kumar S, Joshi D, Soni R, Goel R (2018). Quantitative proteomics of psychotrophic diazotroph in response to nitrogen deficiency and cold stress. Journal of Proteomics 187:235-242. https://doi.org/10.1016/j.jprot.2018.08.005

Suzuki S, Noble AD, Ruaysoongnern S, Chinabut N (2007). Improvement in water-holding capacity and structural stability of a sandy soil in Northeast Thailand. Arid Land Research and Management 21:37-49. https://doi.org/10.1080/15324908601087430

Sylvia DM, Hartel PG, Furhmann J, Zuberer D (2005). Principles and applications of soil microbiology. $2^{\text {nd }}$ Edn., Prentice Hall Inc., Upper Saddle River, New Jersey.

Tan Z, Hurek T, Reinhold-Hurek B (2003). Effect of N-fertilization, plant genotype and environmental conditions on nifH gene pools in roots of rice. Environmental Microbiology 5:1009-1015. https://doi.org/10.1046/j.14622920-2003-00491-X

Tang Y, Zhang W, Zhang M, Chen A, Wei W, Sheng R (2017). Impact of fertilization regimes on diazotroph community compositions and $\mathrm{N}_{2}$-fixation activity in paddy soil. Agriculture, Ecosystems and Environment 247:1-8. https://doi.org/10.1016/j.agee.2017.06.009

Tatusov RL, Fedorova ND, Jackson JD, Jacobs JD, Kiryutin B, Koonin EV, ... Nikolskaya AN (2003). The COG database: An updated version includes eukaryotes. BMC Bioinformatics 4:41. https://doi.org/10.1186/1471-2105-4-41

Tayasu I, Sugimoto A, Wada E, Abe T (1994). Xylophagous termites depending on atmospheric nitrogen. Naturwissenschaften 81:229-231. https://doi.org/10.3410/f.1015729.198003 
Tchan YT, New PB (1984). Genus I Azotobacter. In: Krieg NR, Holt JG (Eds). Bergey's Manual of Determinative Bacteriology. Vol. 1. Williams \& Wilkins, Baltimore, USA, pp 220-229.

Tejera N, Lluch C, Martinez-Toledo MV, Gonzalez-Lopez J (2005). Isolation and characterization of Azotobacter and Azospirillum strains from the sugarcane rhizosphere. Plant and Soil 270:223-232. https://doi.org/10.1007/s11104-004-1522-7

Terakado-Tonooka J, Owaki Y, Yamakawa H, Tanaka F, Yoneyama T, Fujihara S (2008). Expressed nifH genes of endophytic bacteria detected in field-grown sweet potatoes (Ipomoea batatas L.). Microbes and Environments 23:89-93. https://doi.org/10.1264/jsme2.23.89

Thaweenut N, Hachisuka Y, Ando S, Yanagisawa S, Yoneyama T (2011). Two seasons' study on nifH gene expression and nitrogen fixation by diazotrophic endophytes in sugarecare (Saccharum spp. hybrids): expression of nifH genes similar to those of rhizobia. Plant and Soil 338:435-449. https://doi.org/10.1007/s11104-010-0557-1

Thioub M, Ewusi-Mensah N, Sarkodie-Addo J, Adjei-Gyapong T (2019). Arbuscular mycorrhizal fungi inoculation enhances phosphorus use efficiency and soybean productivity on a Haplic Acrisol. Soil and Tillage Research 192:174-186. https://doi.org/10.1016/j.still.2019.05.001

Timothy CE (1999). The presence of nitrogen fixing legumes in terrestrial communities: Evolutionaty vs ecological considerations. Biogeochemistry 46:233-246. https://doi.org/10.1007/bf01007581

Tokuda G, Watanabe H, Hojo M, Fujita A, Makiya H, Miyagi M, ... Arioka M (2012). Cellulolytic environment in the midgut of the wood-feeding higher termite Nasutitermestakasagoensis. Journal of Insect Physiology 58:147-154. https://doi.org/10.1016/j.jinsphys.2011.10.012

Treseder KK, Balser TC, Bradford MA, Brodie EL, Dubinsky EA, Eviner VT, ... Waldrop MP (2012). Integrating microbial ecology into ecosystem models: challenges and priorities. Biogeochemistry 109:7-18. https://doi.org/10.1007/s10533-011-9636-5

Tsoy OV, Ravcheev DA, Cuklina J, Gelfand MS (2016). Nitrogen fixation and molecular oxygen: comparative genomic reconstruction of transcription regulation in Alphaproteobacteria. Frontiers in Microbiology 7:1343. https://doi.org/10.2172/1427520

Ulyshen MD (2015). Insect-mediated nitrogen dynamics in decomposing wood. Ecological Entomology 40(1):97-112. https://doi.org/10.1603/ice.2016.91295

Velmourougane K, Prasanna R, Supriya P, Ramakrishnan B, Thapa S, Saxena AK (2019). Transcriptome profiling provides insights into regulatory factors involved in Trichoderma viride-Azotobacter chroococcum biofilm formation. Microbiological Research 227:126292. https://doi.org/10.1134/s0003683817050179

Verzeaux J, Hirel B, Dubois F, Lea PJ, Tetu T (2017). Agricultural practices to improve nitrogen use efficiency through the use of arbuscular mycorrhizae: basic and agronomic aspects. Plant Science 264:48-56. https://doi.org/10.1016/j.plantsci.2017.08.004

Veselaj E, Sallaku G, Balliu A (2018). Tripartite relationships in legume crops are plant-microorganism-specific and strongly influenced by salinity. Agriculture 8:117. https://doi.org/10.3390/agriculture8080117

Vitousek PM, Menge DNL, Reed SC, Cleveland CC (2013). Biological nitrogen fixation: rates, patterns and ecological controls in terrestrial ecosystems. Philosophical Transactions of the Royal Society B368. https://doi.org/10.1098/rstb.2013.0119

Volpin H, Kapunik Y (1994). Interaction of Azospirillum with beneficial soil microorganisms. In: Okon Y (Ed). Azopirillum/ Plant Association (Florida United State: CRC Press. Inc.).

Wang Q, Garrity GM, Tiedje JM, Cole JR (2007). Naïve Bayesian classifier for rapid assignment of rRNA sequences into the new bacterial taxonomy. Applied and Environmental Microbiology 73:5261-5267. https://doi.org/10.1128/aem.00062.07

Wang Y, Li H, Li J, Li X (2017). The diversity and co-occurrence patterns of diazotrophs in the steppes of Inner Mongolia. Catena 157:130-138. https://doi.org.10.1016/j.catena.2017.05.006

Wani SA, Chand S, Ali T (2013). Potential use of Azotobacter chroococcumin crop production: an overview. Current Agricultural Research 1:35-38. https://doi.org/10.12944/carj.1.1.04

Watson J (1977). The use of mounds of the termite Macroter mesfalciger (gerstacker) as a soil amendment. European Journal of Soil Science 28:664-672. https://doi.org/10.1111/j.1365-2389.1977.tb02273.x

Welsh DT (2000). Nitrogen fixation in seagrass meadows Regulation, plant-bacteria interactions and significance to primary productivity. Ecology Letters 3:58-71. https://doi.org/10.111/j.1365-2389.1976.tb02019.x

Woese CR, Fox GE (1977). Phylogenetic structure of the prokaryotic domain: the primary kingdoms. Proceedings of the National Academy of Sciences of the US 74:5088-5090. https://doi.org/10.1073/pnas.74.11.5088 
Xiao T-J, Yang Q-S, Ran W, Xu G-H, Shen Q-R (2010). Effect of inoculation with arbuscular mycorrhizal fungus on nitrogen and phosphorus utilization in upland rice-mungbean intercropping system. Agricultural Sciences in China 9(4):528-535. https://doi.org/10.1016/s1671-2927(09)60126-7

Xiao Z, Rasmann S, Yue L, Lian F, Zou H, Wang Z (2019). The effect of biochar amendment on N-cycling genes in soils: A meta-analysis. Science of the Total Environment 696:133984. https://doi.org/10.1016/j.scitotenv.2019.133984

Xiao D, Tan Y, Liu X, Yang R, Zhang W, He X, ... Wang K (2020). Responses of soil diazotrophs to legume species and density in a karst grassland, southwest China. Agriculture, Ecosystems and Environment 288:106707. https://doi.org/10.1016/j.agee.2019.106707

Xie X-G, Zhang F-M, Yang T, Chen Y, Li X-G, Dai C-C (2019). Endophytic fungus drives nodulation and $\mathrm{N}_{2}$ fixation attributable to specific root exudates. MBio 10:e00728-19. https://doi.org/10.1128/mbio.00728-19

$\mathrm{Xu} \mathrm{H}$, Shao H, Lu Y (2019). Arbuscular mycorrhiza fungi and related soil microbial activity drive carbon mineralization in the maize rhizosphere. Ecotoxicology and Environmental Safety 182:109476. https://doi.org/10.1016/j.ecoenv.2019.109476

Yang L, Bai J, Zeng N, Zhou X, Liao Y, Lu Y, ... Cao W (2019). Diazotroph abundance and community structure are reshaped by straw return and mineral fertilizer in rice-rice-green manure rotation. Applied Soil Ecology 136:1120. https://doi.org/10.1016/j.apsoil.2018.12.015

Yin Y, Gu J, Wang X, Zhang K, Hu T, Ma J, Wang Q (2018). Impact of copper on the diazotroph abundance and community composition during swine manure composting. Bioresource Technology 255:257-265. https://doi.org/10.1016/j.biortech.2018.01.120

You J, Das A, Dolan EM, Hu Z (2009). Ammonia-oxidizing archaea involved in nitrogen removal. Water Research 43:1801-1809. https://doi.org/10.1016/j.watres.2009.01.016

Yu SS, Ullrich M (2018). Interaction of nitrogen fixation and alginate synthesis of Azotobacter vinelandii isolated from Myanmar mangrove. International Journal of Plant Biology and Research 6(2):1088.

Zehr JP, Jenkins BD, Short SM, Steward GF (2003). Nitrogenase gene diversity and microbial community structure: a cross-system comparison. Environmental Microbiology 5:539-554. https://doi.org/10.1046/j.1462-2920-200300451.x

Zhang X, Han C, Gao H, Cao Y (2019). Comparative transcriptome analysis of the garden asparagus (Asparagus officinalis L.) reveals the molecular mechanisms for growth with arbuscular mycorrhizal fungi under salinity stress. Plant Physiology and Biochemistry 141:20-29. https://doi.org/10.1016/j.plaphy.2019.05.013

Zhang W, Yu C, Wang X, Hai L, Hu J (2020). Increased abundance of nitrogen fixing by higher C/N ration reduces the total losses of $\mathrm{N}$ and $\mathrm{C}$ in cattle manure and corn stover mix composting. Waste Management 103:416-425. https://doi.org/10.1016/j.wasman.2020.04.034

Zhang W, Yu C, Wang X, Hai L (2020). Increased abundance of nitrogen transforming bacteria by higher C/N ration reduces the total losses of $\mathrm{N}$ and $\mathrm{C}$ in chicken manure and corn stover mix composting. Bioresource Technology 297:122410. https://doi.org/10.1016/j.biortech.2019.122410

Zhao L, Liu Y, Yuan S, Li Z, Sun J, Li X (2020). Development of archael communities in biological soil crusts along a revegetation chronosequences in the Tengger Desert, north central China. Soil and Tillage Research 196:204443. https://doi.org/10.1016/j.still.2019.104443

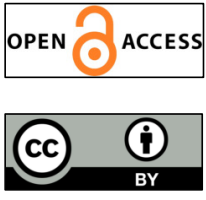

The journal offers free, immediate, and unrestricted access to peer-reviewed research and scholarly work. Users are allowed to read, download, copy, distribute, print, search, or link to the full texts of the articles, or use them for any other lawful purpose, without asking prior permission from the publisher or the author.

License - Articles published in Notulae Botanicae Horti Agrobotanici Cluj-Napoca are Open-Access, distributed under the terms and conditions of the Creative Commons Attribution (CC BY 4.0) License.

(c) Articles by the authors; UASVM, Cluj-Napoca, Romania. The journal allows the author(s) to hold the copyright/to retain publishing rights without restriction. 